norden

\title{
Young workers and sustainable work life
}

Special emphasis on Nordic conditions

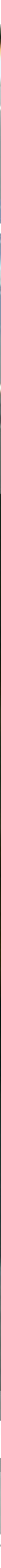







\section{Young workers and sustainable work life}

Special emphasis on Nordic conditions

Hanvold TN, Kines $P$, Nykänen $M$, Ólafsdóttir $S$, Thomée $S$, Holte KA, Vuori J, Wærsted $M$ and Veiersted KB 
Young workers and sustainable work life

Special emphasis on Nordic conditions

Hanvold TN, Kines P, Nykänen M, Ólafsdóttir S, Thomée S, Holte KA, Vuori J,

Wærsted $M$ and Veiersted $K B$

ISBN 978-92-893-4498-2 (PRINT)

ISBN 978-92-893-4499-9 (PDF)

ISBN 978-92-893-4500-2 (EPUB)

http://dx.doi.org/10.6027/TN2016-512

TemaNord 2016:512

ISSN 0908-6692

(C) Nordic Council of Ministers 2016

Layout: Hanne Lebech

Cover photo: Johannes Jansson

Print: Rosendahls Schultz-Grafisk

Copies: 60

Printed in Denmark

This publication has been published with financial support by the Nordic Council of Ministers. However, the contents of this publication do not necessarily reflect the views, policies or recommendations of the Nordic Council of Ministers.

www.norden.org/nordpub

\section{Nordic co-operation}

Nordic co-operation is one of the world's most extensive forms of regional collaboration, involving Denmark, Finland, Iceland, Norway, Sweden, and the Faroe Islands, Greenland, and Åland.

Nordic co-operation has firm traditions in politics, the economy, and culture. It plays an important role in European and international collaboration, and aims at creating a strong Nordic community in a strong Europe.

Nordic co-operation seeks to safeguard Nordic and regional interests and principles in the global community. Common Nordic values help the region solidify its position as one of the world's most innovative and competitive.

\section{Nordic Council of Ministers}

Ved Stranden 18

DK-1061 Copenhagen K

Phone (+45) 33960200

www.norden.org 


\section{Contents}

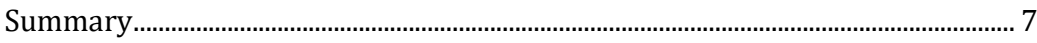

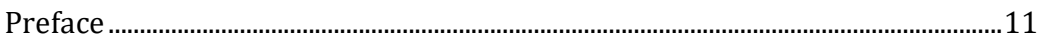

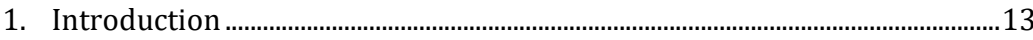

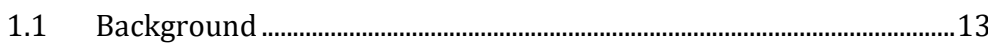

1.2 Objectives...................................................................................................... 15

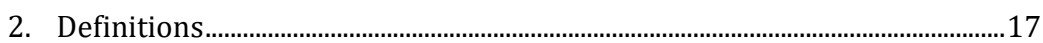

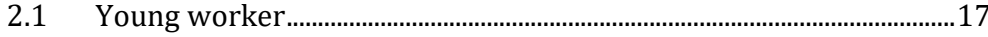

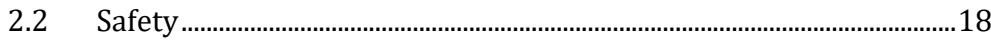

$2.3 \quad$ Health ...................................................................................................................18

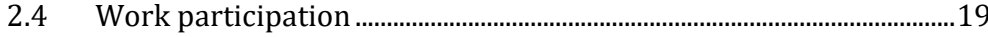

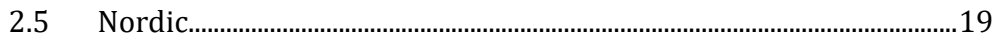

3. Nordic statistics.................................................................................................21

3.1 Materials and Methods ............................................................................21

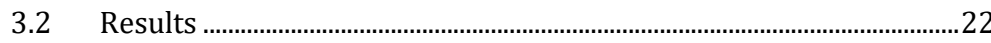

4. Systematic critical literature review.....................................................................39

4.1 Materials and Methods .................................................................................39

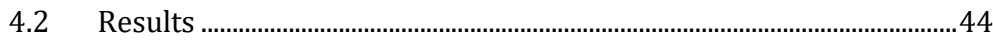

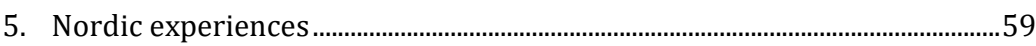

5.1 Materials and Methods ................................................................................5

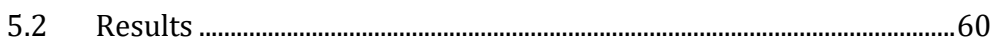

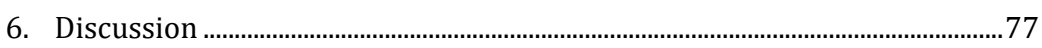

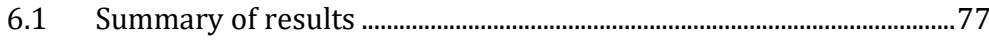

6.2 Youth and worker characteristics ............................................................... 78

6.3 Educational characteristics .......................................................................79

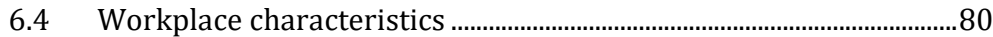

6.5 Employment characteristics ..................................................................8

6.6 Work task characteristics.............................................................................8

7. Conclusions and recommendations ................................................................83

7.1 Ensuring systematic education, introduction, training and

supervision in occupational safety and health........................................83

7.2 Secure and transfer effective initiatives....................................................8

7.3 Improving research regarding young workers......................................84

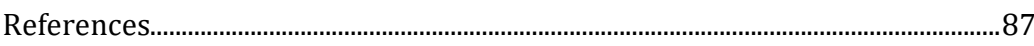

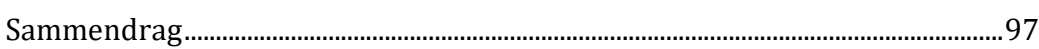





\section{Summary}

The objectives of this report are to compare Nordic statistics on young workers' safety, health and work participation, in addition to systematically and critically review the literature on safety, health and participation among young workers in the Nordic countries. Nordic experiences on challenges and policy initiatives regarding this population are also gathered. Data from Eurostat and National Labour Force Surveys from each country are used to compare the Nordic statistics. The scientific literature published between 1994 and 2014 focusing on young workers in the Nordic countries is reviewed and compared with international studies. Interviews and a one-day Nordic workshop with invited stakeholders are used to gather Nordic experiences.

The national statistics reveal that young workers in the Nordic countries have many similar work-related health challenges. Young workers (aged 15-34) have up to a 40\% increased risk of work-related mental health problems compared with older workers. They have up to a $70 \%$ increased risk of work-related headaches, and an over three times increased risk of work-related skin problems compared to older workers. The literature review shows that occupational chemical substance exposure, handling heavy loads and psychosocial workload are significant risk factors for work-related health problems among young workers in the Nordic countries.

The Nordic statistics show that the young workers are more vulnerable to adverse work exposures. Young workers have up to a $70 \%$ higher risk of reporting heavy physical work, such as handling heavy loads, and almost twice the risk of an accident at work. Highest rates of accidents are found among young workers in farming, forestry and fishing. Young male workers in the Nordic countries are at a higher risk of occupational injury compared to young female workers. However, this is mainly due to young male workers tending to work in workplaces that are more hazardous or having more hazardous tasks compared to female workers. The scientific literature review shows that physically demanding work such as handling heavy loads, psychosocial workload, safety climate and risk socialization are factors associated with occupational accidents among young workers in the Nordic countries. It is evident from this report that there is a lack of studies and knowledge 
concerning the effects of preventive actions regarding young workers' occupational safety and health (OSH) in the Nordic countries. Likewise, there is a lack of knowledge of how company owners and managers perceive $\mathrm{OSH}$, and their role in contributing to a sustainable work life for young workers.

The Nordic stakeholders' experiences underline the importance of avoiding stereotyping young workers, and emphasize that the young workers constitute a heterogeneous group. It is also important to change the focus from the young worker per se, to a broader view on OSH in the workplace and the safety climate in the company where the young people work. Many of the young workers are in unskilled and temporary work, where they often lack OSH training and experience. This underlines the importance of ensuring qualified and structured OSH introductions, supervision and follow up at the workplace.

Based on interviews in the Nordic vocational education systems the report also provides suggestions for improving the OSH education for vocational students. Even though all the five Nordic countries have specific competence goals for OSH knowledge in the vocational educational programs, there is a lack of standardized OSH training, as this is largely influenced by the teacher/school's enthusiasm, experience and available time and resources.

The Nordic countries also face many of the same challenges when it comes to work participation among young adults. The report shows that temporary employment is common among young workers, and that they often work in (more than one) part-time jobs, and have atypical working hours. The employment rates are somewhat different between the countries ranging from $42 \%$ in Sweden to $70 \%$ in Iceland. The scientific literature review shows that early unemployment, low self-rated health, being an ethnic minority and dropping out of school are all associated with low work participation among the young workers in the Nordic countries. Studies have shown that boosting employment preparedness among students of vocational schools results in higher employment rates, and better quality jobs among young workers.

The Nordic experiences on work participation highlights the more unsecure employment environment among young adults. Increasing young adults' preparedness for working life is crucial, however it is clear that work participation among young workers is influenced by multiple factors such as individual, social, occupational and structural conditions.

This report shows that the Nordic countries have many similar challenges and a wide variety of policy initiatives to enhance both OSH and work participation among young workers. The effects of these policy 
initiatives are however rarely evaluated. The current report shows a need for an inter-disciplinary and comprehensive approach to ensure a sustainable work life among young workers. It is essential to take into account the characteristics of the: worker, youth, workplace, work task, education and employment in an attempt to increase our understanding of young workers' health, safety and participation. The findings, conclusions and recommendations in the report will hopefully contribute to improving working conditions for young workers in the Nordic countries through future collaborations, practice, policy initiatives and research in this field. 



\section{Preface}

There are several reasons why studying the health, safety and work participation among young workers are important; one of them is that young workers are faced with potentially harmful exposures to hazardous work environments and conditions to a greater degree than older workers. Young workers also have a higher risk of occupational accidents compared with older workers, and they report higher exposures of e.g. handling heavy loads at work compared with older workers. A significant proportion of young workers are in temporary positions, working irregular/atypical working hours, and there is decreasing employment rate among young adults in the Nordic countries. In order to prevent and reduce accidents and diseases and to increase work participation among young workers there is a need for more knowledge on the transition from school to work, and the health and safety risk factors associated with working life.

The special emphasis on the Nordic conditions in this report is of importance as they face many of the same challenges regarding young workers' health, safety and participation. Similar social structures and systems facilitates comparisons between the five countries and may result in fruitful discussions and exchange of knowledge across borders. Effective initiatives and new ideas are needed in order to increase the sustainable work life for young workers in the Nordic countries.

December 2015, Oslo

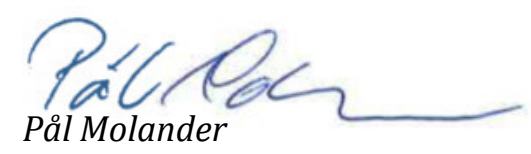

Director General

The National Institute of Occupational Health in Norway 



\section{Introduction}

\subsection{Background}

An aging working population emphasizes the need to provide a sustainable working life for young workers, enabling them to work productively for their entire working life. In order to reduce occupational accidents and diseases and to increase work participation among young workers in the Nordic countries, there is a need for a better understanding of the risk factors associated with occupational accidents and health, and to increase our knowledge on how to facilitate the inclusion of young workers in the labour market. Young workers are faced with potentially harmful exposures to hazardous work (e.g. heavy lifting) to a greater degree than older workers. Young workers are also at higher risk of occupational accidents compared with older workers. In additions, a significant proportion of young workers are temporary workers, working irregular/atypical working hours, and there is a decreasing employment rate among young adults in the Nordic countries.

These challenges have resulted in an increased awareness on the working conditions of young workers. Under the Swedish Presidency of the Nordic Council of Ministers in 2013, young workers were a key focus area. The emphasis on young workers resulted in two TemaNord publications (Halvorsen et al., 2013; Kines et al., 2013). The first report entitled "Young people on the edge - labour market inclusion of vulnerable youths" pointed to common Nordic challenges concerning the high rate of young people not in education, employment or training (5-10\%), and an increasing rate of young people receiving permanent early retirement pensions (2-3\%) (Halvorsen et al., 2013). In the conclusion it was stated that there is a substantial "exclusion" from education and work among young people in the Nordic countries, and that this could contribute to a high percentage of the younger generation having a very weak or no ties to working life for much of their adult life (Halvorsen et al., 2013). In the second report entitled "Young workers' occupational safety and health risk in the Nordic countries", the importance of going beyond seeing young workers as a homogenous group and not focusing on young worker characteristics alone, was emphasized (Kines et al. 2013). It was stated that young workers are a heterogeneous group, whose vulnerability to occupational safety and health risks are highly 
context dependent. The report concluded that there was a need for comparative information from the Nordic countries about the safety and health outcomes for the young workers (Kines et al., 2013).

The current report is a continuation of the focus on young workers initiated by the Nordic Council of Ministers, and has specific attention to three outcomes: 1) occupational safety, 2) health and 3) work participation among young workers with special emphasis on Nordic conditions. The special emphasis on Nordic conditions in this report is based on the sociocultural similarities between the Nordic countries, as the "Nordic model" distinguishes them from other welfare states. The "Nordic model" emphasizes i.e. maximal labour force participation, and the model's success is reflected in the fact that the Nordic countries are among the wealthiest worldwide (World Bank, 2015). The Nordic countries face many similar challenges regarding securing young workers a sustainable work life, yet there are also national differences when it comes to initiatives aimed at young workers' health, safety and work participation. This report provides an opportunity for the Nordic countries to learn from each other and gives a possibility of exchange in ideas, challenges and experiences.

The knowledge that an inter-disciplinary and comprehensive approach is important to ensure a sustainable work life among young workers is an important background for this report and is illustrated in Figure 1. This figure is a modified version of the figure presented in the TemaNord report in 2013 (Kines et al., 2013). The six characteristics listed here all contribute to a sustainable work life for young workers:

- Worker characteristics: Individual characteristics such as, individual health, physical, cognitive and psychosocial maturity level, risk awareness and level of experience.

- Youth characteristics: Social and interpersonal characteristics such as being young and in transition from school to work or from adolescence to adulthood.

- Educational characteristics: The emphasis on occupational safety and health in vocational schools and preparing young adults for work life.

- Workplace characteristics: The social environment and safety culture at the workplace such as OSH introduction, supervision, risk socialization.

- Employment characteristics: Labour market attachment such as part time employment, shift work or irregular working hours.

- Work task characteristics: Work tasks and work exposures such as physical, mechanical, chemical and psychosocial factors. 
Figure 1: Factors contributing to a more sustainable work life among young workers

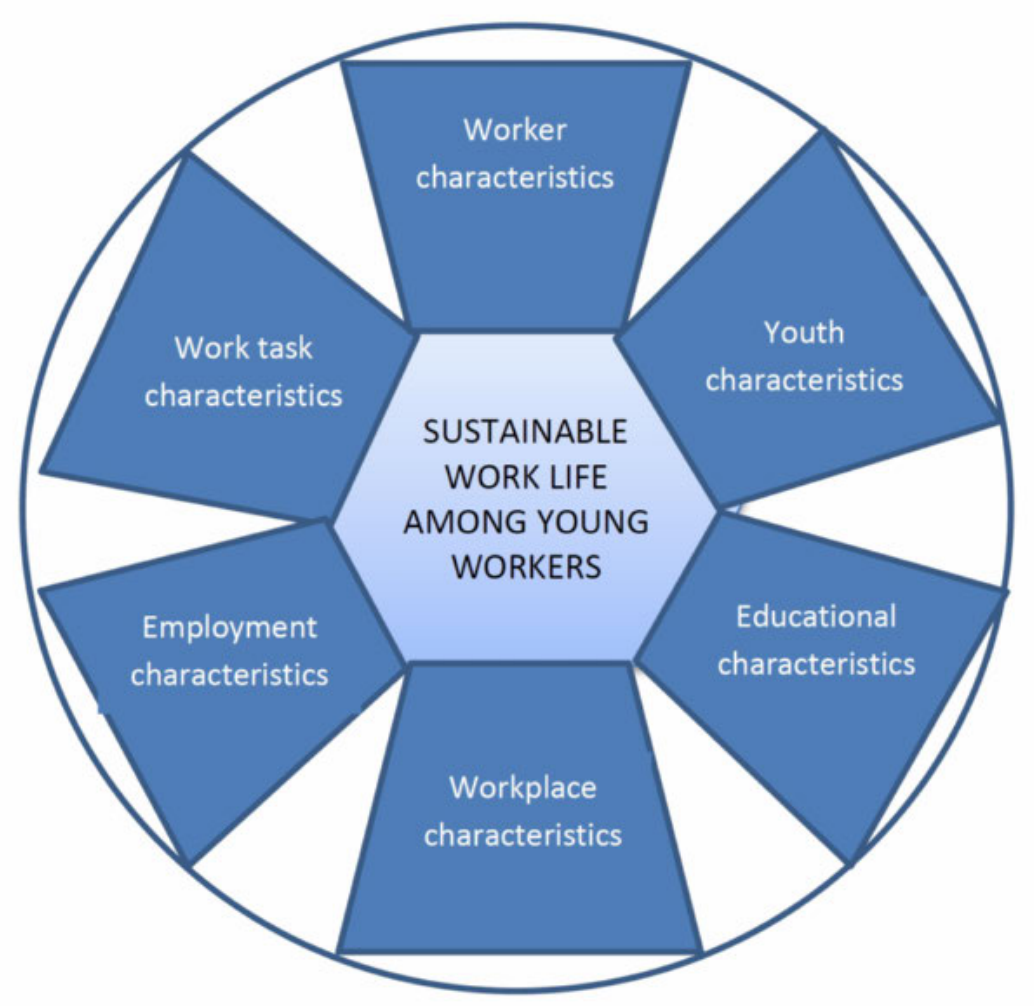

\subsection{Objectives}

The objective of this report is to provide comparisons of national statistics on young workers' work environment, health and work participation from the five Nordic countries. Secondly, to present the results of a systematic critical review of the existing literature concerning risk factors for reduced health, occupational accidents and work participation among young workers in the Nordic countries. The final objective is to gather some Nordic experiences on the challenges faced by young workers in their transition to the labour market, as well as policy initiatives targeted towards young workers' health, safety and work participation. 



\section{Definitions}

Defining the key terms in this report: "young worker", "safety", "health", "work participation" and "Nordic".

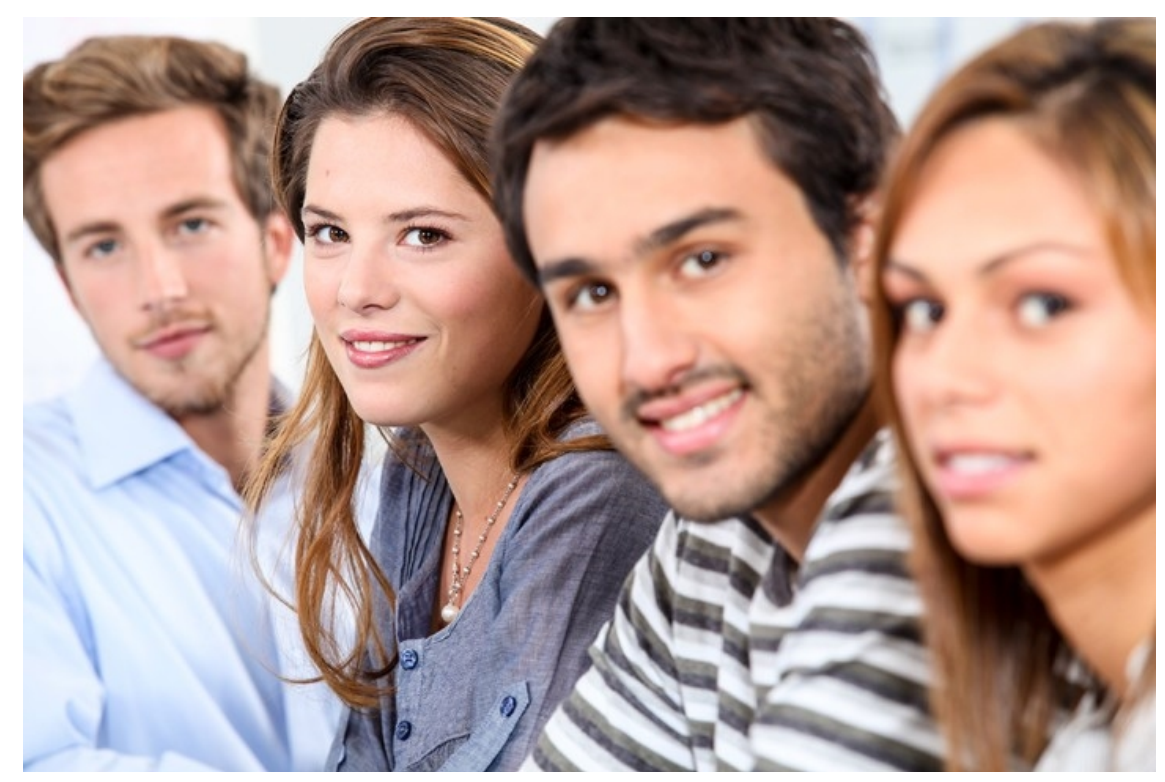

\subsection{Young worker}

There is some ambiguity related to the definition of what constitutes a "young worker". The term may include very different groups, depending on what one regards as being "young", and how one defines "work". The definition often depends on the context: EU legislation directed at protecting young workers defines a "young worker" as under the age of 18 , while some national registers and statistics categorize young workers in the 16-24-year age group. Due to the fact that young people are delaying their transitions into the labor market, often through the extension of higher education, results in EU policy initiatives aimed at young workers tend to be even broader, covering "young workers" up to the age of 30. In Eurostat, statistics are presented with workers aged 1534 , as the "young" group. The term "young worker" is also very different in terms of their working arrangements, as some are students working 
part time, others are full time workers and some are in apprenticeships, while others have more informal or unregistered work such as volunteer work or working for family or friends. In the context of this report, a decision was made to include all categories of paid work, including apprentices, temporary work and part time work. In the literature review it was decided to have a broad view of young workers' age, which subsequently included young people ranging in age from 15-29.

\subsection{Safety}

Safety is the state of being "safe", being protected against the consequences of accidents or physical and psychological harm which could be considered non-desirable. Occupational safety can be defined to be the control of recognized hazards to achieve an "acceptable" level of risk. The common term "occupational safety and health" (OSH) is an area concerned with people's OSH and initiatives to reduce disease and injury. The review in this report includes fatal and non-fatal injuries, as well as a focus on safety culture and climate. Occupational safety and work-related health are treated separately, as an occupational injury is any personal injury or death resulting from an occupational accident, which is $a$ discrete, sudden and unexpected occurrence. This is distinct from workrelated disease which is contracted over a period of time (Eurostat, 1998).

\subsection{Health}

The World Health Organization (WHO) defines health as a state of complete physical, mental and social well-being, and not merely the absence of disease or infirmity (WHO, 1994). A health outcome that is considered work-related is often defined as a condition that is perceived to be caused or made worse by work. Work-related health consequences in this report comprise the effects of long-term strains (noise, chemical, mechanical, physical and psychosocial exposures at work), and the outcomes include mental health, musculoskeletal health and respiratory health, among others. 


\subsection{Work participation}

Work participation is not a well-defined term, however in this report it is used to highlight employment among young workers, and to identify risk factors related with low work participation among this group. Work participation includes terms such as employment rate, temporary employment rate, working hours and inclusion in the labour market after education. Mental and physical health problems and school drop-out are some of the risk factors that may reduce the possibility of gaining a permanent foothold in working life. Unemployment is not a focus of this report.

\subsection{Nordic}

The Nordic countries are a geographical and cultural region in Northern Europe and consist of five countries: Denmark, Finland, Iceland, Norway and Sweden. The term "a young worker in the Nordic countries" in this report refers to people working in one of these Nordic countries. The Nordic countries' autonomous regions, the Åland Islands, the Faroe Islands, and Greenland, are not included in the report. 



\section{Nordic statistics}

\subsection{Materials and Methods}

In order to present and compare Nordic statistics on young workers, we used Eurostat data on self-reported physical and mental health, work environmental exposures, occupational accidents and work participation (Eurostat). Eurostat data are statistics from the EU's statistical office under the European Commission, whose mission is to develop qualitatively comparable statistics for the EU and other countries. Norway and Iceland provide data to Eurostat for most statistical areas, through the European Economic Agreement (EEA). Some of the questions are however posed somewhat differently in the five Nordic countries, resulting in differing levels of reporting. To take this into account the relative risk of reporting occupational accidents, work exposures and health outcomes, were compared between young and older workers and presented for each country. The Eurostat data defines young workers as the age group 15-34 years. In the National statistics in each country, the young workers are defined as 15-24 years. Data from the National Labour Surveys where therefore also used to give a more complete picture.

In Denmark, the National Research Centre for the Working Environment (NRCWE) has large national cohort studies, which include young workers (www.nrcwe.dk). Data from 2013 presented in the report entitled: "Arbejdsmiljø og helbred i Danmark - Resumé og resultater" are used in this report (NFA, 2013).

In Finland, the Finnish Institute of Occupational Health (FIOH) collects surveys every three years on working conditions. Finnish National Work and Health Surveys have targeted Finns aged 20-64 years (population sample) and are collected using computer-assisted telephone interviews. The 2012 data had 2118 respondents, and are presented in the report entitled: "Työ ja terveys Suomessa 2012 Seurantatietoa työoloista ja työhyvinvoinnista" (FIOH, 2012).

For Iceland the main data source used for this report was from the Eurostat database, as other data on work environment were either not available or not age specific. The Icelandic Labour Force Survey was however used regarding shift work and working hours among young workers in Iceland. 
In Norway the Surveillance of Occupational Safety and Health (NOA) provides statistics from the National Labour Survey and National Survey of Living Conditions (http://noa.stami.no). Data from 2013 presented in a report entitled "Faktabok om arbeidsmiljø og helse 2015" are used in this report (NOA, 2015).

The Swedish Work Environment Authority (SWEA) is responsible for the national work environment and work injury statistics, and carries out a survey of work environment and work related disorders biannually. Data from 2013 presented in a report entitled "Arbetsskador 2013, Occupational accidents and work-related diseases" are used in this report (Arbetsmiljöverket, 2014).

\subsection{Results}

\subsubsection{Work-related health and work environment}

\section{Mental health}

In regards to work-related mental health, there is a higher relative risk of reporting symptoms like distress, depression and anxiety among young workers aged 15-34 compared to older workers in all Nordic countries (Figure 2). This is also reflected in the Danish national statistic analyzing young workers aged 18-24, showing that mental health problems decreases with increasing age for men and women. Compared to the mean mental health in the working population, women aged 18-24 have the lowest score (NFA, 2013). In Norway the statistics also show that the young female and male workers (aged 17-24) report more mental health problems compared to older workers (young men $\mathrm{RR}=1.13$, young women RR=1.2) (NOA, 2015). Young workers aged 15-34 also had higher relative risk of reporting work-related headache compared to older workers in all Nordic countries (Figure 3). 
Figure 2: Work-related mental health problems, by age and country, Eurostat 2013

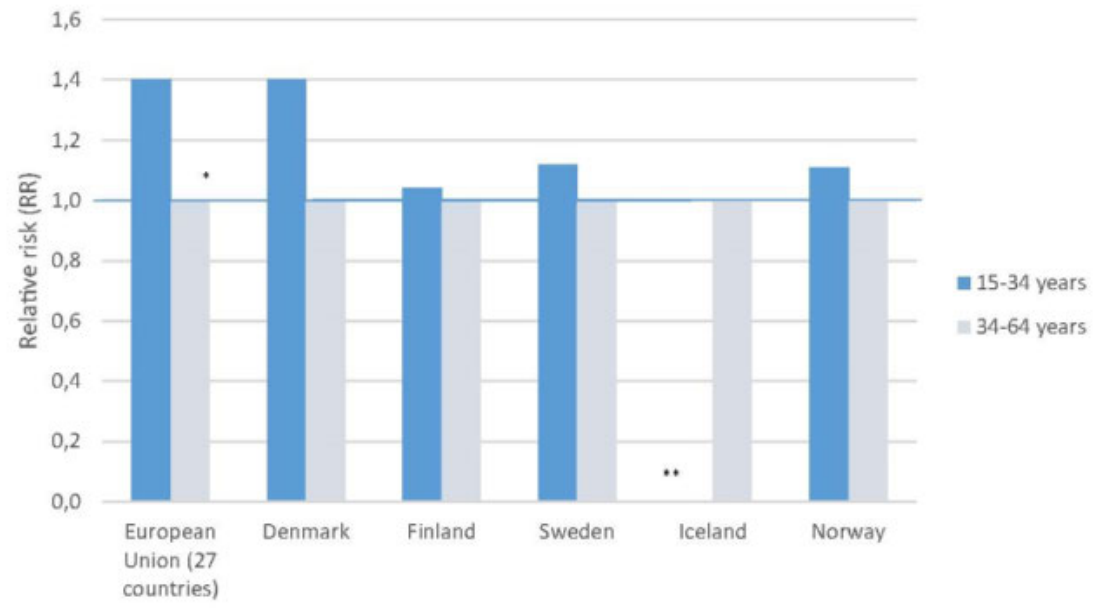

* Data for EU is taken from the 2007 survey.

** Data from Iceland was not available for 15-34 years, data for 35-64 years is from 2007.

Figure 3: Work-related headache, by age and country, Eurostat 2013

2,5

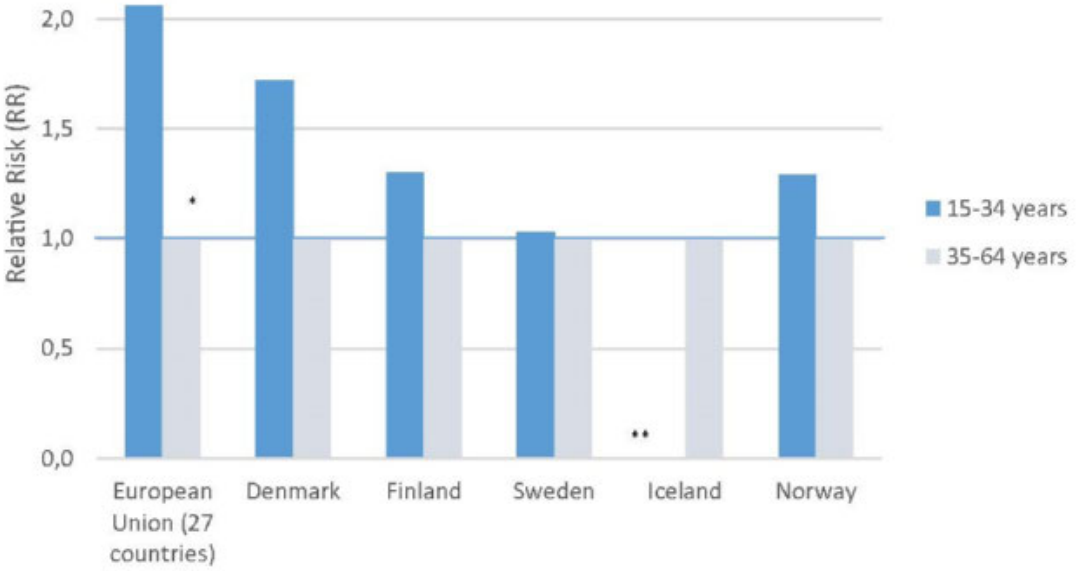

*Data for EU and Iceland is taken from the 2007 survey.

** Data from Iceland was not available for 15-34 years, data for 35-64 years is from 2007. 


\section{Musculoskeletal health}

The statistics from Eurostat show a consistently lower prevalence of workrelated musculoskeletal health problems among young workers aged 1534 compared to older workers in all the Nordic countries. Figure 4 shows that the relative risk for reporting work-related musculoskeletal problems were lower among young workers than among their older colleagues. Among young male workers in Norway, there was a 30\% lower relative risk for both back pain and neck/shoulder pain compared with older male workers. Among young and older female workers, there was no difference in the relative risk for musculoskeletal pain (NOA, 2015). According to Finnish National Work and Health Survey (2012), there was lower prevalence of work-related musculoskeletal health problems among young workers aged 20-24 compared to older workers.

Figure 4: Work-related musculoskeletal problems, by age and country, Eurostat 2013

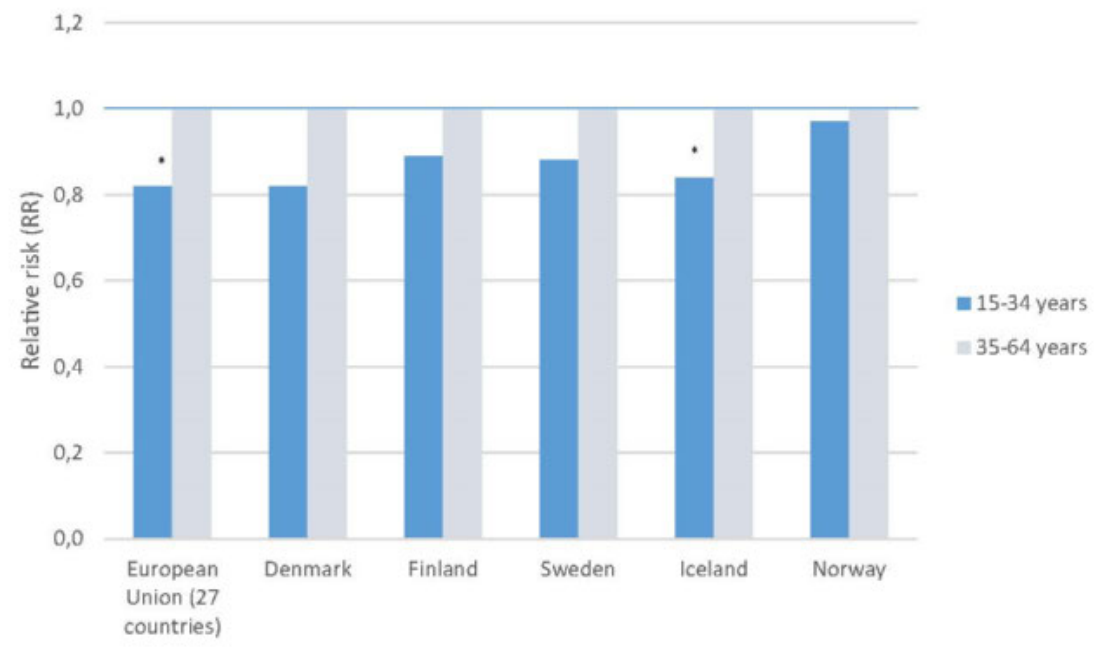

*Data for EU and Iceland is taken from the 2007 survey.

\section{Dermatological health}

The statistics from Eurostat show that young workers aged 15-34 have much higher risk for work-related skin problems compared to older workers in all the Nordic countries that had comparable data (Figure 5). Eurostat data from Finland shows that young workers have over 3 times more skin problems compared to workers aged 35+. The Danish statistics also show that young workers aged 18-24 report dermatological hand symptoms more often than older workers, and that almost one in three report to have had hand skin problems (NFA 2013). 
Figure 5: Work-related skin problems, by age and country, Eurostat 2013

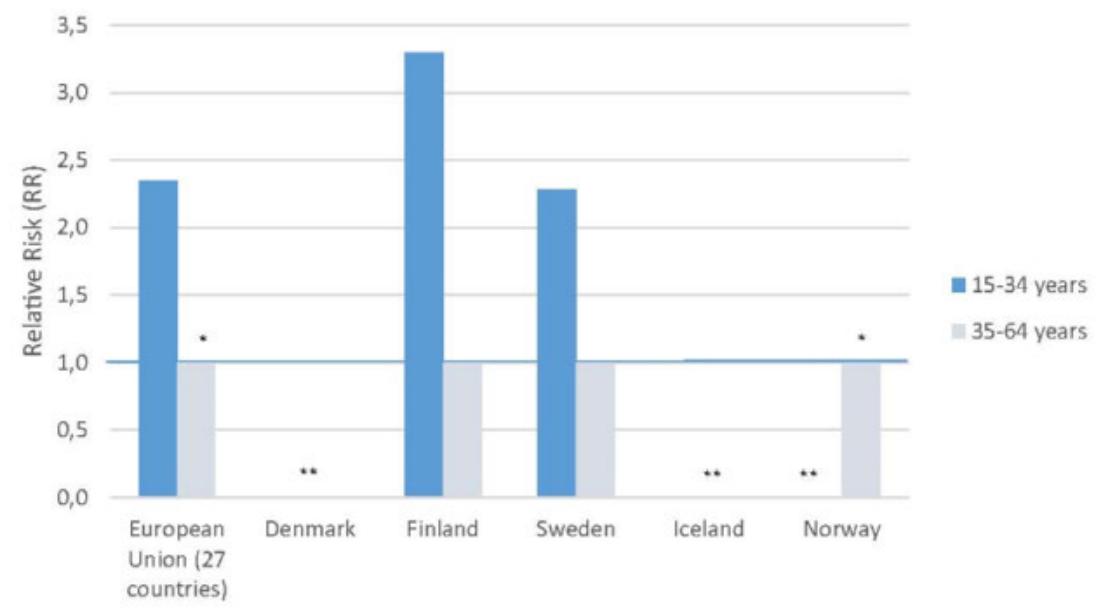

*Data for EU and Norway are taken from the 2007 survey.

** Data from Iceland and Denmark (all), Norway (15-34 years) were not available.

\section{Psychosocial work environment}

Statistics from Eurostat show that young workers in the Nordic countries aged 15-34 report lower prevalence of time pressure at work compared to their older colleagues (Figure 6). Swedish statistics show that both young male and female workers (aged under 30) report more support from colleagues and superiors, compared to older workers. Young workers in Denmark also report higher prevalence of social support from colleagues than older workers (Arbetsmiljöverket 2014). This is also seen in Norway as both young women and men have a lower risk of reporting role conflicts and low levels of social support (NOA, 2015). At the same time as having high social support the young workers in the Nordic countries report less job control, with young workers in Sweden reporting lower control over work organization (Arbetsmiljöverket, 2014). Young workers in Norway (aged 17-24) also report lower prevalence of job control than their older colleagues. Approximately $60 \%$ of the young men had a higher risk of reporting the combination of low control and high demands than older male workers. Young women had a higher prevalence of the combined exposure than their older colleagues (NOA, 2015). The Danish Survey also shows that young men and women (aged 14-24) had lower control over how and when a job should be done (NFA, 2013). According to the Finnish National Work and Health Survey (2012), younger workers (20-30 years old) did not have to rush $(35 \%$ quite or very often) as often to get work done as older workers (45\%). 
Younger workers also got more support from line manager and colleagues than older workers. One out of three young workers (35\%) could influence the length of their working day very or quite much, in comparison with $38 \%$ of older workers. One in four young $(26 \%)$ had to be flexible daily or weekly in working times, either because the job required it or management asked for it ( $24 \%$ of older workers).

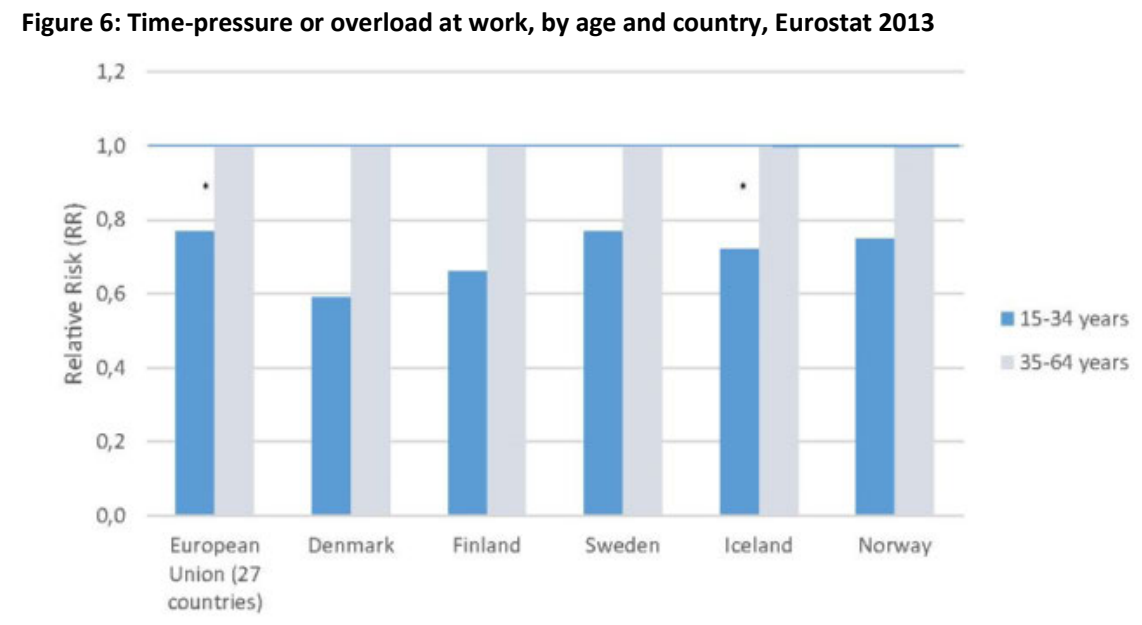

*Data for EU and Iceland is taken from the 2007 survey.

The statistics from Eurostat also show that young workers in the Nordic countries aged 15-34 experience less harassment and bullying compared to their older colleagues, except for young workers in Sweden (Figure 7). When looking at young workers aged 17-24, the Norwegian Survey showed that young women reported somewhat more sexual harassment compared to older women, yet at the same time were less exposed to bullying at work. Young male workers had a higher prevalence of bullying than older male workers (NOA, 2015). In Denmark, they also found that young female workers (aged 18-34) were more exposed to sexual harassment (NFA, 2013). In Iceland, bullying was most frequently experienced by female workers under 30 years (Sigursteinsdottir 2012). About $41 \%$ of workers in the service sector experienced sexual harassment and approximately $68 \%$ of those were under the age of 24 (Rögnvaldsdottir 2015). The Finnish Institute of Occupational Health also collected biannually data on working conditions in the municipal sector in the 10-Town-Study. In 2012, the youngest group of workers (18-24) experienced more mental (verbal intimidation) and physical violencerelated situations (especially kicking and striking) than the older age groups (Kunta 10-tutkimus, 2012). 
Figure 7: Harassment or bullying at work, by age and country, Eurostat 2013

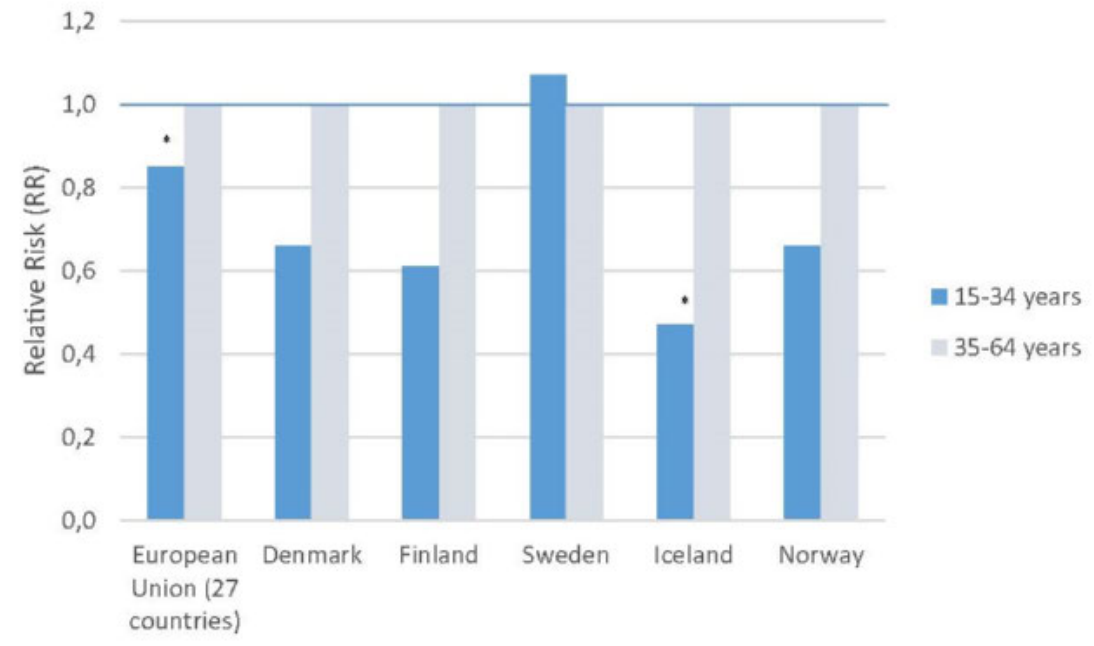

*Data for EU and Iceland is taken from the 2007 survey.

\section{Mechanical and physical work environment}

According to the Eurostat statistics, young workers in the Nordic countries are more exposed to handling heavy loads compared to their older colleagues (Figure 8). In the Danish Survey, young workers reported that their work involves higher physical demands compared to their older colleagues. They also are more exposed to walking and standing, lifting, carrying, and squatting than older workers (NFA, 2013). The same is also the case in Norway, as statistics show that young women and men (aged 17-24) had an $80 \%$ higher risk of reporting physical work exposure compared to older workers. Among the young women, 50\% reported awkward lifting, while $22 \%$ of the older female workers reported the same. Among the male workers, $72 \%$ reported squatting, while $45 \%$ of the older male workers reported the same (NOA, 2015). Young workers in Sweden (aged under 30) also reported more physically demanding work, repetitive work and work in awkward postures, compared with workers $\geq 30$ years of age (Arbetsmiljöverket, 2014). According to the Finnish Work and Health Survey, young workers in Finland also reported more physically demanding work than older workers (FIOH 2012). 
Figure 8: Handling heavy loads at work, by age and country, Eurostat 2013

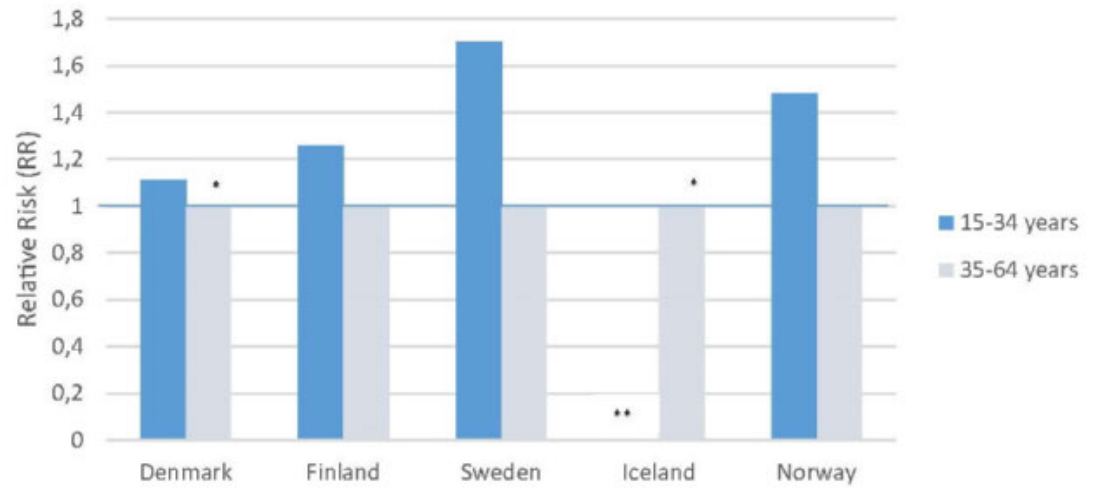

*Data for EU and Iceland is taken from the 2007 survey.

** Data from Iceland (15-34 years) were not available.

According to the data from Eurostat exposure to work-related noise and vibration is more common among older workers in the Nordic countries than young workers (Figure 9). However, national statistics reveal that exposure to noise at work has a higher prevalence among both young male and female workers in Norway compared to older workers. Young male workers were also more exposed to vibration than older men $(52 \%$ and 30\%, respectively) (NOA, 2015). In Denmark there was a high prevalence of noise exposure for more than $1 / 4$ of the working day among young male workers aged 18-24 (NFA, 2013).

Figure 9:Noise or vibration at work, by age and country, Eurostat 2013

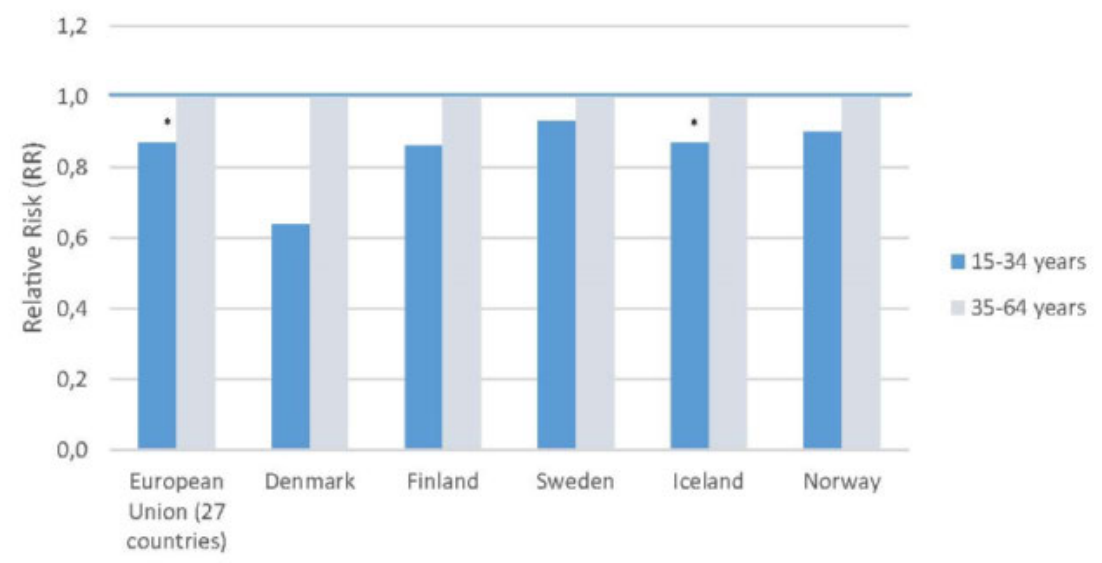

*Data for EU and Iceland is taken from the 2007 survey. 


\section{Chemical work environment}

Exposures to chemicals, dust, fumes, smoke or gases are according to Eurostat more common for older workers in Finland, Iceland and to some degree in Denmark compared to young workers. In Norway and Sweden young workers reported higher chemical work exposure than older workers (Figure 10). When looking at the national statistics, Danish statistics show that young workers aged 18-24 were more exposed to chemicals to the skin than older workers. They were also more exposed to work with wet hands than their older colleagues (NFA, 2013). In Norway, young female workers had an $80 \%$ higher risk of being exposed to chemical cleaning products and wet hands compared to their older colleagues. Young male workers in Norway had a 50\% higher risk of being exposed to chemical cleaning products compared to their older colleagues (NOA, 2015).

Figure 10: Chemicals, dust, fumes or gasses at work, by age and country, Eurostat 2013

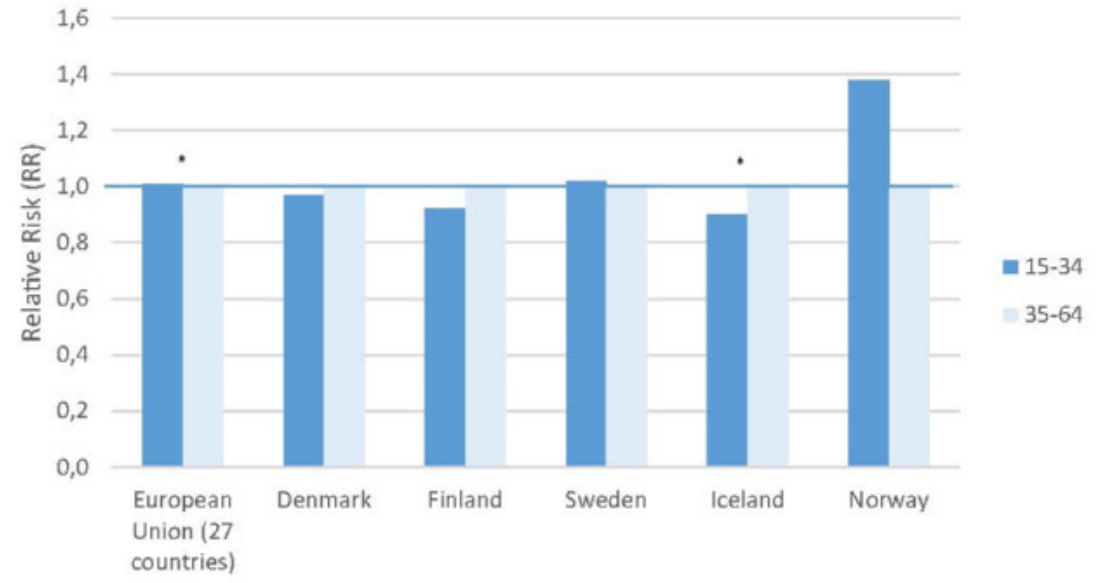

*Data for EU and Iceland is taken from the 2007 survey. 


\subsubsection{Occupational accidents}

Figure 11: Accidents at work, by age and country, Eurostat 2013

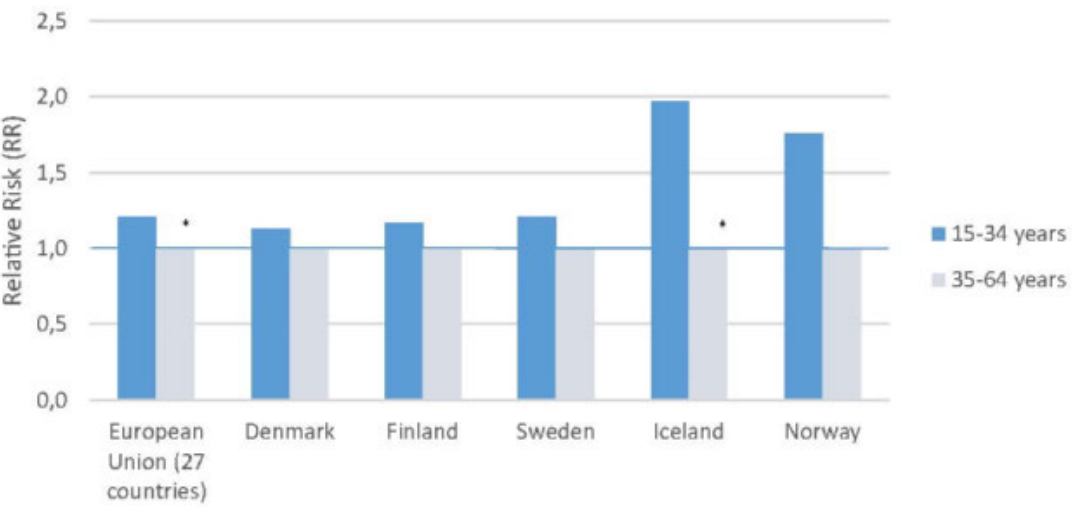

*Data for EU and Iceland is taken from the 2007 survey.

\section{Occupational accidents}

Fatal occupational accidents in the Nordic countries were compared in a recent TemaNord report, and the authors found similar trends in the five countries, with the highest prevalence among middel aged workers (3554 years), and with a high predominance among men (Tómasson et al., 2011). According to Eurostat data from 2013, young workers had a higher prevalence of reporting an accident at work compared to older colleagues (Figure 11). This is consistent in all five Nordic countries, and is also found in the EU countries.

Figure 12: Accidents at work among men, by age and country, Eurostat 2013

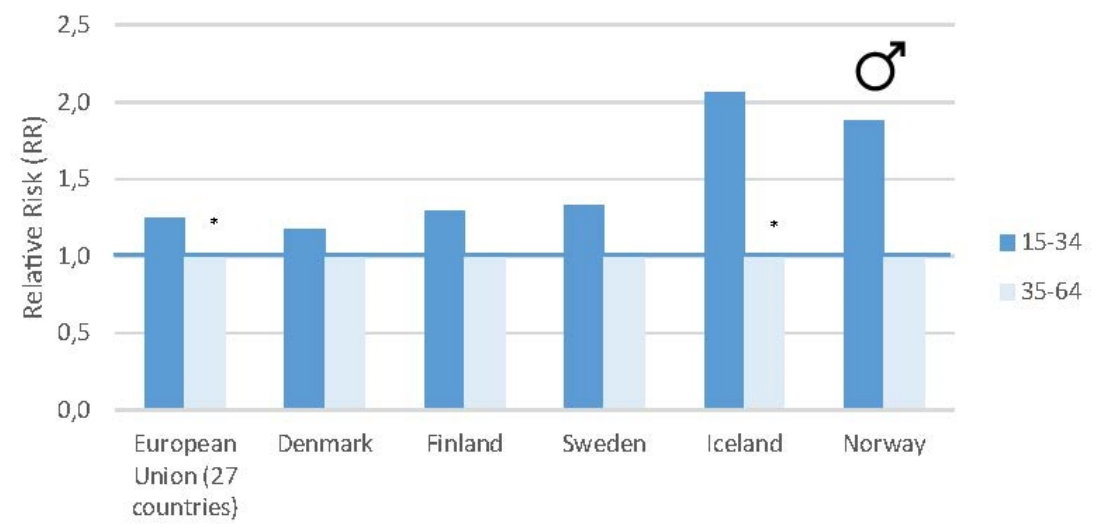

*Data for EU and Iceland is taken from the 2007 survey. 
In Denmark statistics show that young male workers aged 18-24 had a higher prevalence of accidents at work (last 12 months) than young women. Danish statistics also showed that young men had a 1.4 times greater risk for accidents at work compared to older male workers, whereas young female workers had 1.8 times greater risk for accidents at work (NFA, 2013). In Norway 5.7\% of young male workers aged 16-24 reported an injury due to an accident at work (last 12 months). The mean for all male workers (aged 16-67) was 3.1\%. Among the young women, $4.5 \%$ aged $16-24$ reported an injury due to an accident at work. The mean for all female workers (aged 16-67) was 2.6\% (NOA, 2015). In Sweden young men have the highest frequency of accidents at work, with an almost $40 \%$ higher accident frequency compared with male workers in all other age groups. For women, workers between 55-59 showed the highest accident frequency (Arbetsmiljöverket 2014). In Iceland a representative sample of $13-17$ year olds $(n=2,000)$ showed that $20 \%$ had experienced an accident at work (no comparison to older workers). Boys were at greater risk than girls (Einarsdóttir et al., 2014). In Finland, younger workers (aged 20-24) had a higher risk of work accidents than older workers, with $19 \%$ of young male and $17 \%$ of young female workers aged 18-24 reporting an injury due to an accident at work (last 12 months) (FIOH, 2012).

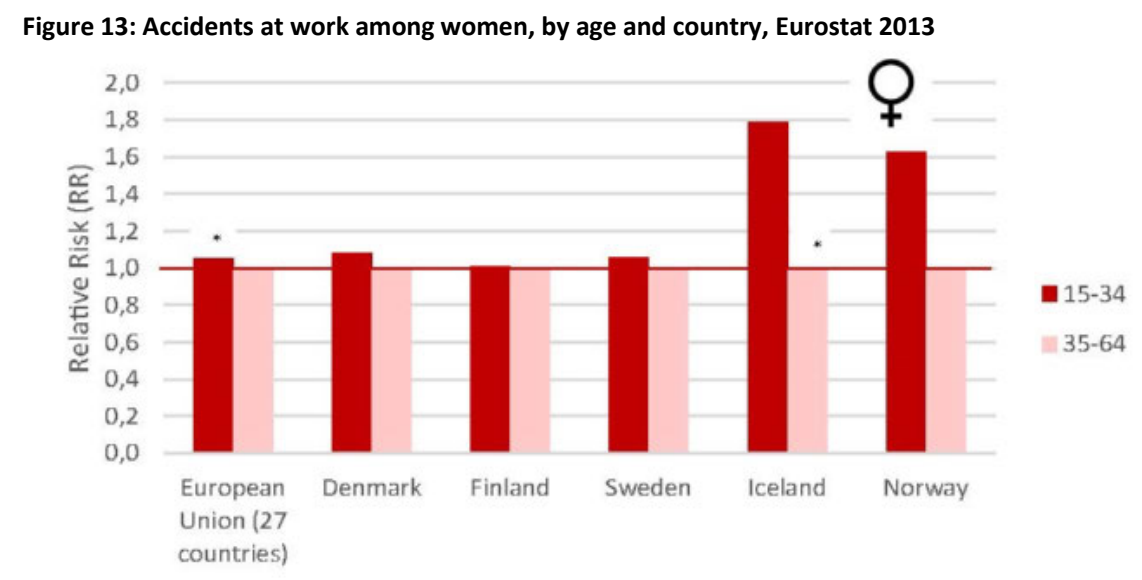

*Data for EU and Iceland is taken from the 2007 survey.

It has been shown previously that occupational accidents, regardless of age, have their highest prevalence in branches like construction, manufacturing and agriculture (NOA, 2015). Table 1 and 2 clearly show that young workers in the Nordic countires (aged 15-24) have a higher prevalence of occupational accidents compared to older workers, 
regardless of branch or company size. It is however important to recognize that among the young workers in the Nordic countries farming, forestry, fishing and construction are the branches with highest prevalence of accidents at work. There is however, no clear pattern of the prevalence of occupational accidents related to company size. In small as well as medium and large companies, young workers are at higher risks of reporting an accident at work compared to older colleagues (Table 2).

Table 1: Persons reporting an accident at work (2013) by age, country and occupation (Eurostat) Prevalence pr. 1,000 workers

\begin{tabular}{|c|c|c|c|c|c|c|c|c|c|c|}
\hline \multirow[b]{2}{*}{ Age } & \multicolumn{2}{|c|}{ Denmark } & \multicolumn{2}{|c|}{ Finland } & \multicolumn{2}{|c|}{ Sweden } & \multicolumn{2}{|c|}{ Iceland* } & \multicolumn{2}{|c|}{ Norway } \\
\hline & $15-34$ & $35-64$ & $15-34$ & $35-64$ & $15-34$ & $35-64$ & $15-34$ & $35-64$ & $15-34$ & $35-64$ \\
\hline $\begin{array}{l}\text { Professionals } \\
\text { (Managers, profession- } \\
\text { als, technicians and } \\
\text { associate professionals) }\end{array}$ & 2.9 & 2.7 & 4.9 & 5.3 & 2.7 & 3.3 & - & 3.2 & 2.1 & 1.5 \\
\hline $\begin{array}{l}\text { Service and sales } \\
\text { (Clerical support work- } \\
\text { ers, service and sales } \\
\text { workers) }\end{array}$ & 4 & 4 & 10.5 & 8.6 & 6.7 & 6.3 & 8.9 & - & 4.6 & 2.9 \\
\hline $\begin{array}{l}\text { Farming, forestry and } \\
\text { fishing } \\
\text { (Skilled agricultural, } \\
\text { forestry and fishery } \\
\text { workers, craft and relat- } \\
\text { ed trades workers) }\end{array}$ & 7.6 & 7.4 & 19.1 & 15.1 & 11.2 & 9.3 & 12.1 & 5.9 & 9.3 & 4.4 \\
\hline $\begin{array}{l}\text { Construction } \\
\text { (Plant and machine } \\
\text { operators and assem- } \\
\text { blers, elementary } \\
\text { occupations) }\end{array}$ & 4.5 & 4.2 & 14.2 & 10.5 & 7.1 & 6.7 & 12.1 & - & 5.0 & 4.3 \\
\hline
\end{tabular}

*Data for Iceland is taken from the 2007 survey.

Table 2: Persons reporting an accident at work (2013) by age, country and size of enterprise (Eurostat) Prevalence pr. 1,000 workers

\begin{tabular}{|c|c|c|c|c|c|c|c|c|c|c|}
\hline \multirow[b]{2}{*}{ Age } & \multicolumn{2}{|c|}{ Denmark } & \multicolumn{2}{|c|}{ Finland } & \multicolumn{2}{|c|}{ Sweden } & \multicolumn{2}{|c|}{ Iceland* } & \multicolumn{2}{|c|}{ Norway } \\
\hline & $15-34$ & $35-64$ & $15-34$ & $35-64$ & $15-34$ & $35-64$ & $15-34$ & $35-64$ & $15-34$ & $35-64$ \\
\hline $\begin{array}{l}\text { Small company } \\
\text { (10 employees or fewer) }\end{array}$ & 3.2 & 2.6 & 10.9 & 9.4 & 4.8 & 4.9 & 8.5 & - & 1.5 & 2.3 \\
\hline $\begin{array}{l}\text { Medium company } \\
\text { (From } 11 \text { to } 49 \text { employees) }\end{array}$ & 4.7 & 4.0 & 10.9 & 8.5 & 6.5 & 5.8 & 7.6 & 3.7 & 5.9 & 2.4 \\
\hline $\begin{array}{l}\text { Large company } \\
\text { (50 employees or more) }\end{array}$ & 5.0 & 3.5 & 8.3 & 6.2 & 5.4 & 4.4 & 9.5 & 4.1 & 5.3 & 2.4 \\
\hline
\end{tabular}

*Data for Iceland is taken from the 2007 survey. 


\section{Safety climate}

Young workers in Denmark rate their safety climate as poorer, in terms of perceiving minor accidents as a normal part of their daily work, than older colleagues. They report to be less often included in decision making regarding safety, and to a lesser degree are encouraged to work safely during times of high work pressure. Female workers aged 18-24 experienced to a lesser degree that they received the necessary guidance and instruction to safely carry out their work, than older women (NFA, 2013). Young workers may also tend to blame themselves for an accident, which has occurred. In a survey done by the Norwegian Labour Inspection Authority, over half of the workers that were injured due to lack of safety equipment stated that the accident could have been avoided if they had done something differently (Søvik et al., 2009).

\section{Safety knowledge}

In Norway the Directorate for Education commissioned NTNU in 2013 to conduct an Apprentice Survey, which is an electronic-based survey where apprentices can voice their opinions on important matters of their training. A sample of 2,976 apprentices from eight counties participated (6,691 invited: response rate 44\%), in which one of the themes highlighted was OSH. The survey showed that nearly $90 \%$ of the apprentices reported that they had knowledge of the rules for safety at their workplace to a quite large or large degree. Male apprentices reported to have higher knowledge on the rules for safety at their workplace than female apprentices. Apprentices from industry production and electrical trade had the highest score (4.16) on OSH knowledge (scored on a scale 1-5), while apprentices from design and handcraft had the lowest scores (3.5). It was also shown that apprentices in companies with over 100 employees reported higher OSH knowledge (4.2) than apprentices in companies with 1-5 employees (3.8) (Wendelborg et al., 2014).

Even though there are clearly stated OSH competence goals for vocational education in all five Nordic countries, the exact quantity and quality of the training is up to each school and often the individual teacher. This means that young workers can start out with very different levels of knowledge regarding occupational safety and health.

In Iceland IĐAN, The Vocational education and training Centre, sent questions on OSH (comparable to the Norwegian Apprentice Survey) to 253 apprentices, and 80 valid responses were obtained (response rate $32 \%$, two thirds of the respondents were male). This small sample may give a hint on how Icelandic vocational students perceive their own $\mathrm{OSH}$ knowledge, even though the sample is not representative. The results 
showed that $75 \%$ have knowledge of the rules for safety at their workplace to quite large or large degree. Half of the respondents knew to a quite large or large degree what work procedure to follow if the safety measures are not followed, and $85 \%$ knew what to do to a quite large or large degree if there was an accident at the workplace.

In Finland, there is also information on young worker's OSH training and knowledge. In 2006 The Finnish Institute of Occupational Health carried out a survey entitled "Young people and work barometer" (Sulander et al., 2006). A randomized sample included 1,865 young people (aged 15-29) and 1,025 young people took part in the survey (telephone interviews). Some OSH questions were asked to those aged 15-19 and 20-24 who were at work. Results showed that over $90 \%$ men and women aged 15-24 reported to have received sufficient guidance related to working practices at their workplace. On the question "Have you been told about your work-related hazards and safety regulations?" three out of five respondents had received information on occupational hazards and safety regulations of work or machinery and equipment. However, approximately $20 \%$ of young people had not received enough or no information at all. Young male workers reported having received more information on OSH compared to young female workers.

\subsubsection{Work participation}

An earlier report from the Nordic Council of ministers highlighted the increasing number of young adults in the Nordic countries that are at risk of long-lasting exclusion from working life (Halvorsen et al., 2013).

\section{Employment rate}

Statistics on youth employment by age and sector in the Nordic countries have recently been presented in a TemaNord report from 2013 (Halvorsen et al., 2013). They found that young workers in the Nordic countries are employed in sectors like wholesale/retail trade, accommodation/food/beverage services, health services and construction. Data from 2014 show the same picture as the most frequent youth employment was in wholesale/retail, $28 \%$ in Iceland $21 \%$ in Finland and $47 \%$ in Norway. Accommodation/food/beverage services also had high youth employment frequency (18\% in Iceland, $10 \%$ in Finland and $43 \%$ in Norway). Construction had a lower youth employment frequency (4\% in Iceland, $8 \%$ in Finland and $13 \%$ in Norway), as well as farming, fishing and forestry (2\% in Iceland, $4 \%$ in Finland). Concerning the youth employment rate, Eurostat statistics show that there are differences in the Nordic countries as it in 2013 varied from 
$42 \%$ in Sweden and Finland to $70 \%$ in Iceland for $15-24$ year olds. All Nordic countries had a higher employment rate than the European Union mean (Figure 14). A distinction for the transition to adulthood in Iceland is the high work participation of young people. Findings from the longitudinal research project Youth of Iceland indicate that at least $60 \%$ of pupils in upper secondary schools worked alongside studying (termtime work) in 2007 (Kristjánsson et al., 2008; Einarsdóttir, 2014).

Figure 14: Employment rate 2004-2013, by country. Age 15-24, Eurostat

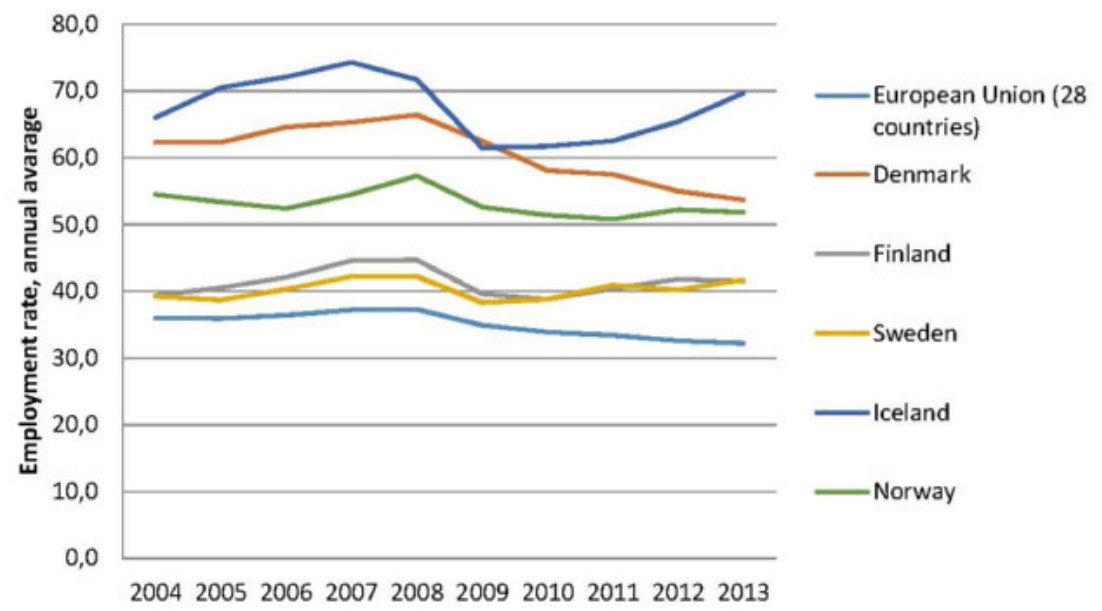

Note: Statistical concept and definition: Employed persons are all persons who worked at least one hour for pay or profit during the reference week or were temporarily absent from such work.

\section{Temporary employment rate}

Forty-five percent of young employees working in Europe have temporary jobs. Temporary employment among young workers is also high in the Nordic countries, and Norwegian statistics show that the majority of temporary employment is among young workers $<34$ years of age (NOA, 2015). According to the Finnish Work and Health Survey (2012), younger workers (aged 20-30) worked in permanent employment less often (65\%) than older workers (89\%), and also in regular day work less often (59\%) than older workers (72\%). In all the Nordic countries temporary work is highest among young workers aged 15-24. Data from Eurostat show that temporary employment varies greatly between the Nordic countries with Denmark (21\%) and Norway $(28 \%)$ having the lowest percentage of young employees in temporary job. While Finland (48\%) and Sweden (62\%) had the highest percentage of young temporary employees (Figure 15). 
Figure 15: Temporary employment 2012-2014, by country. Age 15-24, Eurostat

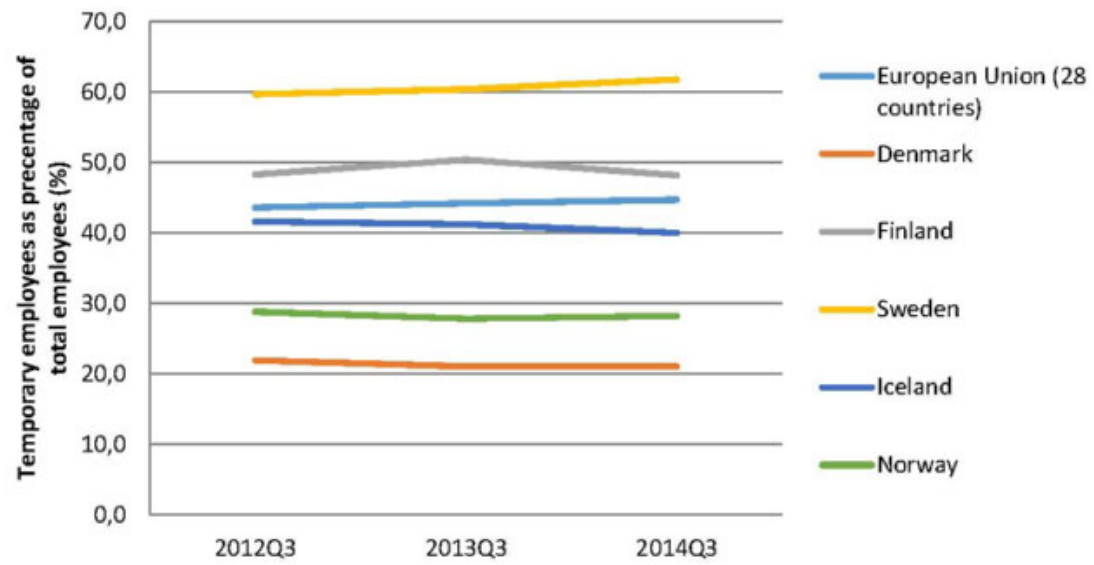

\section{Shift work or atypical working hours}

Working atypical working hours is more prevalent among young workers compared to older workers in the Nordic countries. Twenty nine percent of young Norwegian workers aged 17-24 reported working shift work compared with $11 \%$ of workers aged $25+$. Young workers also reported more atypical workhours (16\%) compared to workers 25+ (4\%). Daytime work was reported by $59 \%$ of the young workers (aged 17-24) and $80 \%$ of the workers 25+ (NOA, 2015). In Finland the Finnish Quality of Work Life Survey from 2013 showed that the prevalence of shift work decreased with age; $60 \%$ of the young workers aged $15-24$ had shift work compared to $30 \%$ of workers aged 35-44. Forty percent of young workers in Finland reported daytime work compared to $70 \%$ among workers aged 35-44. In Sweden, the Survey of Living Conditions from 2014 showed that shift work was reported by $36 \%$ of workers, aged $16-24$, while $22 \%$ of all workers reported shift work (age 16-64). Young workers in Sweden also report more atypical workhours (45\%) compared to all workers (32\%). According to the Icelandic Labour Force Survey the prevalence of shift work is higher among young workers aged 17-24 (53\%) than among those 25 years and older (19\%). Working untraditional working hours (evenings, nights, Saturdays and Sundays) was also more common among young workers aged $17-24(51 \%)$ than workers 25 year or older $(24 \%)$.

\section{Sustainable work life}

Eurostat have calculated the duration of working life in all European countries. The number of years a person is expected to be active in work life in the five different Nordic countries is illustrated in Figure 16, showing that Iceland had the most sustainable work life of the Nordic countries. Finland 
had the lowest number of years in working life of the Nordic countries, but still well above the mean of the other European countries.

Figure 16: Duration of working life indicator by country. Eurostat

$$
50,0
$$

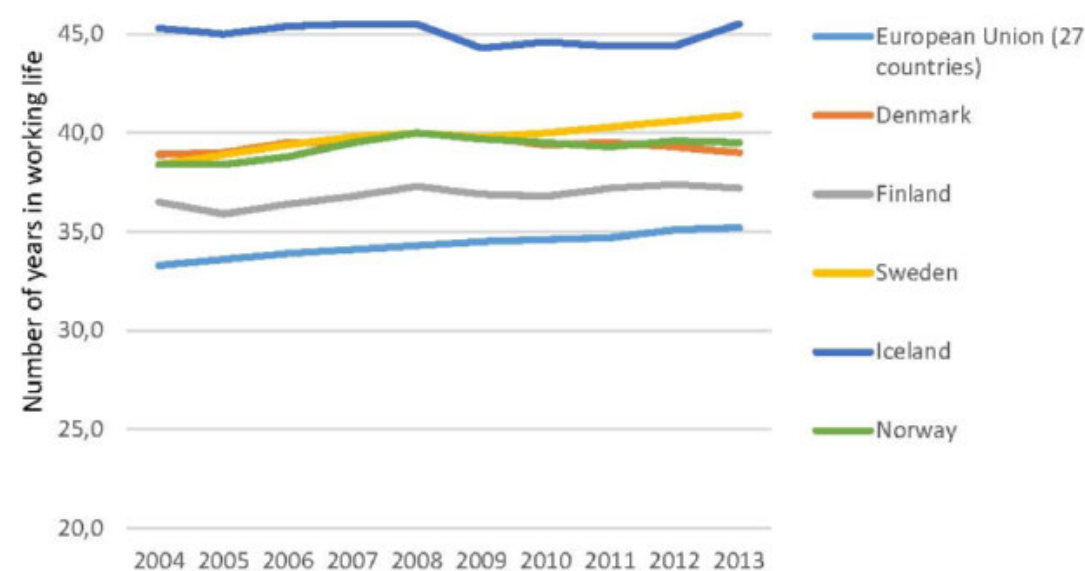

Note: Statistical concept and definition: The duration of working life indicator measures the number of years a person aged 15 is expected to be active in the labour market throughout his/her life. This indicator is calculated with probabilistic model combining demographic data (Life tables available from Eurostat to calculate the survival functions) and labour market data (Labour Force Survey activity rates by single age group). 



\section{Systematic critical literature review}

\subsection{Materials and Methods}

To better understand the risk factors associated with occupational accidents, work-related health and work participation among young workers, a literature review of studies on young workers in the Nordic countries was conducted.

\subsubsection{Literature search}

The following five databases were consulted: (1) Ovid Medline, (2) Ovid Embase, (3) Web of Science, (4) ProQuest health and Safety Sciences Abstract, and (5) Psycinfo. In addition, each of the project members searched through their own archives to add any additional papers that were published in peer reviewed journals not indexed in the five databases that were consulted. To optimize the search several test searches were conducted, adapting it to improve the sensitivity. All the project members selected "must have" articles in the field, and the search was tested concerning if it captured all the "must have" articles. The final database search was conducted in collaboration with a librarian, in April 2014. The search consisted of a combination of free text terms and the hierarchic controlled vocabulary, which was customized for each database. The free text terms combined three groups of terms (Work, Young, Nordic) using "AND". The terms in group1 included e.g. work*, occupation*, career, job, employee, profession* etc. The terms in group 2 included e.g. young, teen*, apprentice*, youth* etc. Finally, the third group of terms were e.g. Nordic, Sweden, swede*, scandinavia*, Danish, etc. The terms in each of the three groups were then combined with "OR". (The text terms and $\mathrm{MeSH}$ terms are included in the accompanying on-line document http://dx.doi.org/10.6027/TN2016-512 and attachments). The search strategy was developed with low specificity and high sensitivity, meaning that there was a high probability of hits on potentially relevant studies. The disadvantage is that a large number of studies must be evaluated for their relevance. The systematic, critical 
literature review included only peer-reviewed, original articles published (indexed) in the period between 1994 and April 2014. The number of hits from each database is presented in Table 3.

Table 3: Review of young workers in the Nordic countries 1994-2014: Database search results

\begin{tabular}{lrr} 
Databases & Date & Hits \\
& & \\
Embase & 14.04 .2014 & 4,519 \\
Medline & 14.04 .2014 & 5,565 \\
Health \& Safety Abstracts & 23.04 .2014 & 1,682 \\
PsyclNFO & 22.04 .2014 & 2,694 \\
Web of Science & 23.04 .2014 & 1,846 \\
Sum & & 16,306 \\
Duplicates & & 3,778 \\
Sum of retrieved papers & & 12,528 \\
\hline
\end{tabular}

\subsubsection{Inclusion of papers}

The inclusion process is presented in a flowchart (Figure 17). Two reviewers (TNH) and (MW) independently screened the titles of each of the 12,528 papers. Based on the papers agreed upon, they further independently screened 1767 abstracts based on the inclusion and exclusion criteria of the study (Table 4). When the two reviewers did not agree on the inclusion or exclusion of a paper, a third reviewer (KBV) was consulted and a consensus was reached. One hundred and thirty one fulltext papers were assessed to ensure they met the inclusion criteria using the same screening methods. Eighty-two papers met the inclusion criteria. Four additional papers were included from the authors' archives. Two papers on occupational injuries was found in a new journal not yet indexed in the five databases searched (Nordic Journal of Working Life Studies) (Nielsen 2012; Nielsen et al. 2013). Two papers on work participation that were not found in the search (Koivisto et al. 2007; Koivisto et al. 2010), but which both fulfilled the inclusion criteria, were also included. 
Table 4: Review of young workers in the Nordic countries 1994-2014: Inclusion and exclusion criteria

\begin{tabular}{|c|c|c|}
\hline & Inclusion & Exclusion \\
\hline Study type & $\begin{array}{l}\text { Qualitative studies } \\
\text { Quantitative studies } \\
\text { - Prospective } \\
\text { - Cross-sectional } \\
\text { - Intervention } \\
\text { - Case-Control }\end{array}$ & $\begin{array}{l}\text { Commentary articles } \\
\text { Review articles } \\
\text { Studies which are not peer-reviewed }\end{array}$ \\
\hline $\begin{array}{l}\text { Population of } \\
\text { interest: Age }\end{array}$ & $\begin{array}{l}\text { Studies where one or more of the } \\
\text { categorized populations is included in the } \\
\text { age range15-29 }\end{array}$ & $\begin{array}{l}\text { Studies where people aged } 15-29 \text { and are } \\
\text { part of a bigger population, but not } \\
\text { analyzed separately }\end{array}$ \\
\hline $\begin{array}{l}\text { Population of } \\
\text { interest: workers }\end{array}$ & $\begin{array}{l}\text { Studies with focus on workers or } \\
\text { transition to work } \\
\text { Work includes: paid work, apprentices, } \\
\text { trainee, part time work, informal } \\
\text { employment, temporary work }\end{array}$ & $\begin{array}{l}\text { Studies that focus on young adults with no } \\
\text { focus on work } \\
\text { Professional athletes } \\
\text { Military training } \\
\text { Birth cohorts which focus on factors in } \\
\text { childhood and work disability }\end{array}$ \\
\hline $\begin{array}{l}\text { Population of } \\
\text { interest: Nordic } \\
\text { conditions }\end{array}$ & $\begin{array}{l}\text { Studies that include populations from the } \\
\text { Nordic countries }\end{array}$ & $\begin{array}{l}\text { Studies where populations from the Nordic } \\
\text { countries are part of a larger population, } \\
\text { but not analyzed separately }\end{array}$ \\
\hline Outcomes & $\begin{array}{l}\text { Occupational accidents/injuries } \\
\text { Work related health } \\
\text { Low work participation, work } \\
\text { inclusion/exclusion }\end{array}$ & $\begin{array}{l}\text { Outcomes with no relevance to work } \\
\text { Drug use and alcoholism }\end{array}$ \\
\hline Risk factors & $\begin{array}{l}\text { A clearly defined risk factor including: } \\
\text { safety culture, attitudes, mechanical } \\
\text { factors, physical factors, psychosocial } \\
\text { factors, gender, industry, sector, } \\
\text { profession, family background etc. }\end{array}$ & $\begin{array}{l}\text { No risk factors are defined or analyzed in } \\
\text { the study } \\
\text { Studies on young workers and wage } \\
\text { incitement, or economic regression/crises } \\
\text { in society as exposure variables }\end{array}$ \\
\hline Language & $\begin{array}{l}\text { Studies that are written in English or one } \\
\text { of the Nordic languages }\end{array}$ & \\
\hline Publication period & Studies published from 1994 to April 2014 & \\
\hline
\end{tabular}




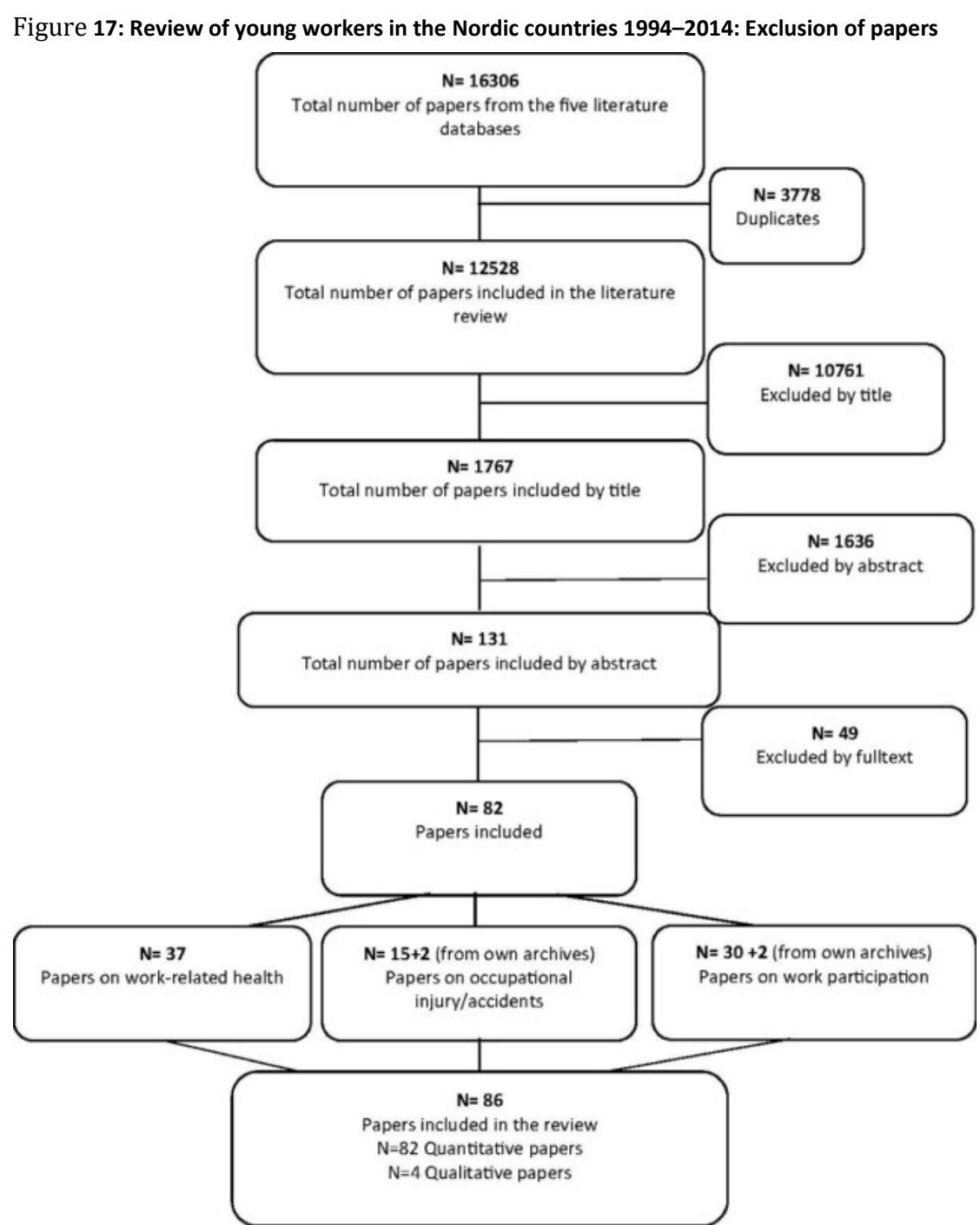

\subsubsection{Assessment of scientific quality and strength of association}

To assess the methodological quality of the 82 quantitative papers included in this review, a modified version of a previously used quality schemes was used (Knardahl et al., 2008; van Tulder et al., 2003). The form was developed to give each paper a score based on its internal and external validity. The internal validity assessed five different areas: (1) Study population, (2) exposure/risk factor measurements, (3) outcome measurements, (4) analysis and data presentation, and (5) confounders. Each outcome (work-related health, occupation injury and low work 
participation) had a separate form, as did the different study designs (cross-sectional, prospective, case-control and intervention) (The quality scheme and the table of results from each paper are included in the accompanying on-line document http://dx.doi.org/10.6027/TN2016-512 and attachments).

The four qualitative papers were quality assessed using the "Standard Quality Assessment for Evaluating Primary Research Papers from a Variety of Fields" (Kmet et al., 2004). The assessment was based on: (1) Clarity of the research question, (2) appropriateness of design, (3) context and sampling, (4) data collection and analysis, and (5) conclusions and reflexivity.

Two reviewers rated the quality assessment of each paper independently, and a consensus was reached when the two quality assessment forms were compared. If consensus was not reached, a third reviewer was consulted. The 86 papers were shared between the project members (TNH, PK, MN, ST, KAH, JV, MW and KBV), and divided so that none of the project members quality assessed papers where they themselves were authors. Prior to the quality assessment, quality assessment training was carried out, by assessing relevant papers and discussing ambiguities that emerged. The quality assessment was used to weight the results from the different papers, and to ensure that all papers had acceptable quality.

To assess the strength of association between the outcomes and exposures in this review the following categories were used:

- Evidence of an association: The evidence is based on experimental and observational studies of moderate/high quality, and where several reinforcing circumstances are present.

- Limited evidence of an association: The results are based on observational studies of high or moderate quality, but there are ambiguous results.

- Insufficient evidence of an association: The evidence does not permit decisions regarding an association or not between the exposure and outcome as there are too few or no studies.

The assessment of an association in this review does not imply that there is a direct causal relationship between the exposure/risk factor and the outcome. Many factors may influence the relationships, e.g. young age may be associated with accidents (but being young is not a direct risk factor in itself), the exposure to work tasks, training, workplace factors. The strength of association in this review is based on papers among young 
workers in the Nordic countries, excluding any relevant international studies. Thus, this assessment does not intend to apply as a general assessment of the evidence.

\subsection{Results}

The results are presented separately for the three outcomes: (i) occupational accidents and injuries, (ii) work-related health, and (iii) low work participation.

\subsubsection{Occupational accidents}

Seventeen papers on occupational accidents or injuries were included, with seven of them carried out on populations in Sweden, and six in Norway. Three papers studied young workers in Denmark and one in Finland. No papers were found on occupational injuries and accidents among youth in Iceland. Seven of the 17 studies involved workers between 16 and 24 years of age. Three papers studied those between 20-24 years. The age group 1824 was studied in two of the studies, while another two papers defined young workers as under 30 years of age. The age groups 16-20,18-23 and 15-18 were all studied in one paper each. The study design, methodological quality and the risk factors studied in each paper are listed in Table 5. The 17 papers concern various types of injuries such as fractures, bruises, cuts and affect different body part such as specific injuries to eyes or fingers. None of the papers analyzed fatal occupational accidents. The majority of papers (12 of 17) were prospective studies based on register data, which provided accident rates among different occupational groups, gender and age groups. The data were taken from national databases or from injuries reported by emergency units over a specific period. These studies were mainly descriptive, and did not control for other individual or work-related factors than age, gender and occupation. The two other quantitative papers evaluated physical and psychosocial work factors associated with occupational injures by controlling for relevant confounders (Kjestveit et al., 2011; Rasmussen et al., 2011). The three qualitative papers that were focused on involved: i) organization of OSH training, based on company size (Holte and Kjestveit, 2012), ii) how safety and risks are experienced among young employees (Nielsen, 2012), and iii) how risks are experienced among different groups of young workers (Nielsen et al., 2013). There were no papers on the evaluation of interventions to decrease accidents or injuries. 
Table 5: Review of young workers in the Nordic countries 1994-2014: Studies regarding occupational accidents and injuries $(n=17)$

\begin{tabular}{lll} 
& Risk factor/Exposure /Intervention & Study Quality (internal validity) \\
\hline $\begin{array}{l}\text { Prospective (registers) } \\
(n=12)\end{array}$ & $\begin{array}{l}\text { Accident rates among different } \\
\text { occupational groups and age groups }\end{array}$ & Mean score: $33.6 \%$ (range 4-54\%) \\
$\begin{array}{l}\text { Prospective(follow-up) } \\
(n=1)\end{array}$ & Physical and psychosocial work factors & Score: $64 \%$ \\
Cross-sectional $(n=1)$ & Physical and psychosocial work factors & Score: $52 \%$ \\
Qualitative design ( $n=3)$ & $\begin{array}{l}\text { How OSH training is organized, how risk } \\
\text { and safety are experienced }\end{array}$ & $\begin{array}{l}\text { Mean score: } 61.6 \% \\
\text { (range } 45-80 \%)\end{array}$ \\
\hline
\end{tabular}

\section{Summary of associations}

Gender: Three articles studied gender and found a gender difference in injury rates, indicating that young male workers had a greater risk of occupational injury than young female workers. In one Swedish paper men had 67 injuries per 1,000 workers, while women had 14 (Lindqvist et al., 1999). Injury rates in Norway for men were found to be two (Bull et al., 1999) and three (Gravseth et al., 2003) times greater than for women. These were all prospective register papers with data from the general working population, and did not control for gender difference in exposure to hazardous jobs or workplaces. Conclusion: There is evidence that young male workers in the Nordic countries are at a higher risk of occupational injury compared to young female workers. In a Canadian review of occupational injuries among young workers they found that young males are about twice as likely to sustain a work injury as their female counterparts. However, multivariate studies show that the gender differences are primarily due to the fact that young males tend to work in more hazardous workplaces (Breslin et al., 2005).

Occupation/Industry: One paper found higher eye injury rate among young workers in the metal industry compared to other industries (Bull et al., 2004), while another paper found that among the general working population, electricians and carpenters had greater risk of injury (Gravseth et al., 2003). Conclusion: The evidence suggests that there are different injury rates within different occupations.

Safety climate/risk behaviour: A Finnish prospective study found that incautiousness(carelessness) was an important contributing accident factor for young workers, and that feeding and cleaning machines was the main work task related to accidents for young workers (Salminen, 1996). Two qualitative studies that used focus group interviews of young workers from different workplaces highlighted the interaction between safety 
climate and risk behavior. One paper suggests that risk behavior is linked to what is the acceptable risk, and often reflects the risk culture in the organization or occupation (Nielsen, 2012). The other paper further emphasizes the structural and cultural work environment surrounding the young workers, and that different types of work tasks may lead to different exposures to risk (Nielsen et al., 2013). These two qualitative studies suggest that safety climate and risk behavior are linked, and that they may be associated with occupational injury. In one Norwegian paper with a cross-sectional design the safety climate at the workplace was not associated with an increased risk of injury among young workers in the construction industry (Kjestveit et al., 2011). Conclusion: There is evidence of an association between safety climate and risk behavior and accidents and injuries among young workers in the Nordic countries. Risk behavior at the workplace may occur for example, in neglect of safety regulations, underestimation of risk of accidents or desire to "show-off" or "prove oneself" to other workers or colleagues. Young people may not be aware of workplace hazards, or they may assess them differently (Loughlin, 2004). The review suggests that safety climate and risk behavior are linked, and that they may be associated with occupational injuries.

Nationality: In a Swedish register study a slight tendency of higher accident frequency rate was found among immigrant employees (mostly from Finland) over 25 years of age, compared with employees with Swedish nationality (Döös et al. 1994). This was however, the only paper assessing nationality as a risk factor among young workers. Conclusion: There is insufficient evidence of an association between nationality and injury rates among young people working in the Nordic countries. Only one study on minorities and occupational accidents makes it impossible to draw any firm conclusions. However, international studies have found that being an ethnic minority can be associated with occupational injuries because of difference in job training, language barriers and differential hazardous exposures (Breslin et al., 2005).

Physical/Mechanical work factors: Mechanical workload such as heavy lifting and physical work factors such as vibration were associated with increased injury risk in a cross-sectional study among young construction workers (Kjestveit et al., 2011). A prospective study following the same workers from the age of 15 to when they were 18 found that heavy lifting increased the risk of experiencing occupational accidents (Rasmussen et al., 2011). Conclusion: There is evidence suggesting an association between mechanical work factors such as heavy lifting and occupational accidents among young workers in the Nordic countries. An earlier review covering the global literature however, found 
evidence that perceived work overload was correlated with work injury among youth (Breslin et al., 2005).

Psychosocial work factors: Low control over work pace was associated with increased risk of injury in a cross-sectional study among young construction workers (Kjestveit et al., 2011). A prospective study following the same workers from the age of 15 until they were 18 found that psychosocial factors at work, such as low social support and psychological demands, increased the risk of experiencing work-related accidents among young workers (Rasmussen et al., 2011). Conclusion: There is evidence suggesting an association between psychosocial work factors and occupational accidents among young workers in the Nordic countries. An earlier review covering the global literature however, found evidence that feeling rushed was correlated with work injury among youth (Breslin et al., 2005).

Interventions: Several of the papers included in this review state in the concluding remarks that their results point to potential preventive actions. Some also suggest preventive measures aimed at young workers, such as better on-the-job training and closer follow-up by experienced workers (Bull et al., 2001). However, no published studies were found from the Nordic countries regarding the effect of occupational injury prevention on young workers. There were however studies highlighting the need for future experimental studies on different effects of preventive measurements (Gravseth et al., 2003). Conclusion: In the Nordic countries, there is a lack of studies and knowledge concerning the effects of preventive actions regarding young workers and occupational injuries/accidents. There are however quite a number of intervention studies on occupational accidents among workers in general. A recent systematic literature review evaluating the effect of different safety interventions identified 156 studies. Based on these studies six main types of safety interventions were characterizes:

1. changes in knowledge and attitudes

2. physiological changes and use of personal protective equipment

3. changes in behavior

4. changes in norms, safety culture and climate

5. structural changes such as physical or organizational environment

6. an integrated intervention with combinations of the changes in 1-5 (Dyreborg et al., 2013). 
Findings from the review showed that structural safety measures and integrated safety measures seem to be most effective in reducing accidents at work. These findings are not based on young workers in particular, yet may nevertheless be relevant when discussing interventions for young workers, and in planning intervention studies among young adults.

\subsubsection{Work-related health}

Twelve of the 37 papers on work-related health were based on Swedish populations, 11 papers came from Denmark while eight papers were of Norwegian origin. Six papers studied young workers from Finland, while no papers were found from Iceland. The age groups studied had a mean age ranging from 17.5 to 35 . In addition, the age groups analyzed varied considerably in range (i.e. population aged 16-30, 16-24, 20-34 and 1664). The study designs, methodological quality and risk factors studied in each paper are listed in Table 6. The 37 papers on work-related health concern mental health, musculoskeletal health, work ability, productivity, auditory symptoms, respiratory symptoms and skin reactions.

\begin{tabular}{|c|c|c|}
\hline & Risk factor/Exposure /Intervention & Study Quality (internal validity) \\
\hline Prospective $(n=18)$ & $\begin{array}{l}\text { Mechanical workload }(n=8) \\
\text { Psychosocial work factors }(n=10) \\
\text { Occupational flour dust }(n=1) \\
\text { Occupational noise }(n=1) \\
\text { Employment status }(n=1)\end{array}$ & Mean score: $61 \%$ (range $54-79 \%$ ) \\
\hline Cross-sectional $(n=15)$ & $\begin{array}{l}\text { Psychosocial work factors }(n=2) \\
\text { Mechanical workload }(n=2) \\
\text { Occupational vibration }(n=1) \\
\text { Chemical exposures in hairdressing }(n=5) \\
\text { Dust among farmers and bakers }(n=3) \\
\text { Occupational noise }(n=1) \\
\text { Educational level }(n=1) \\
\text { Health as a risk factor for sickness absence } \\
(n=1)\end{array}$ & Mean score: $61.6 \%$ (range $31-81 \%$ ) \\
\hline Intervention $(\mathrm{n}=3)$ & $\begin{array}{l}\text { Skin protection training and low back } \\
\text { training program }\end{array}$ & Mean score: $54.6 \%$ (range $42-62 \%$ ) \\
\hline Case-control $(n=1)$ & $\begin{array}{l}\text { Respirable dust exposure among former } \\
\text { farmers }\end{array}$ & Score: $61 \%$ \\
\hline
\end{tabular}




\section{Summary of associations}

Gender: Fifteen papers assessed gender differences in relations to workrelated health. Seven papers addressed musculoskeletal symptoms among both male and female young workers, and all found a gender difference. Significantly, more women reported low back pain or low back injuries compared to males (Hagberg et al., 2005; Mikkonen et al., 2012). Neck and shoulder pain were also more prevalent among women compared with men (Hanvold et al., 2010; Hanvold et al., 2013). Two studies found that women had an increased risk of musculoskeletal symptoms and aches, pain and numbness, compared to men (Khatun et al., 2004; Korpinen and Paakkonen 2011). Two papers assessed productivity and workability and found no gender difference among young workers (Boström et al., 2008; Boström et al., 2012). Six papers studying mental health among young workers found no gender difference in burnout/exhaustion (Dahlin et al., 2010; Hultell and Gustavsson 2011) suicidal thoughts (Tyssen et al., 2001a), work-related stress (Tyssen et al., 2005) and mental problems (Tyssen et al., 2000; Tyssen et al., 2001b). Conclusion: There is evidence that young females report more musculoskeletal health problems compared to male workers in the Nordic countries. There is insufficient evidence of an association between gender and work-related mental health problems. Note that four of the six papers on gender and mental health were done by the same authors.

Chemical occupational substance exposure: Four Danish papers studied the association between exposures to chemical substances among young hairdressers and skin reactions, e.g. hand and wrist eczema. Three of the papers found the exposures to chemicals such as hair dying products increased the risk of experiencing skin reactions and hand eczema (Bregnhøj et al., 2011b); Lind et al., 2007; Lysdal et al., 2011). There was however one paper contradicting this result. It found that fewer hairdressers had hand eczema compared with a control group (Bregnhøj et al., 2011a). The authors suggested that this could be interpreted as a healthy worker effect among the young hairdressers. An intervention study educating teachers in vocational schools in skin physiology, allergy and skin protection showed significantly reduced hand eczema among the hairdressers in the intervention group (Bregnhøj et al., 2012). Another paper evaluated the association between exposures to chemical products and airway symptoms such as wheezing and runny nose among young hairdressers in Norway. The results showed that hairdressers under the age of 30 reported more airway symptoms compared to office workers in the same age group (Hollund et al., 2001). 
Conclusion: Based on studies among Nordic workers there is evidence suggesting an association between occupational chemical substance exposure among young hairdressers and skin reactions, e.g. hand eczema. This is in line with International studies such as a German study among hairdresser apprentices where unprotected wet work was associated with adverse skin changes (Uter et al., 1999). There is however insufficient evidence of an association between chemical occupational substance exposure and airway symptoms among young workers in the Nordic countries.

Occupational dust exposure: Three papers studied the association between occupational dust exposure and respiratory symptoms in young farmers (Hoffmann et al., 2003; Omland et al., 1999; Sigsgaard et al., 1997). Two of the studies found no association between occupational farming exposure at a young age and lung symptoms or lung function (Omland et al., 1999; Sigsgaard et al., 1997). Hoffmann et al (2001) however, found that acute exposure to organic dust containing endotoxin among male former farmers lead to weak systemic inflammatory response (Hoffmann et al., 2003). Young bakers are also exposed to dust (e.g. flour dust), and the association with respiratory symptoms was reported in two papers (Skjold et al., 2008; Skjold et al., 2007). Both found no significant associations. However, another paper from the same research group showed that rhinitis and asthma like symptoms were commonly developed in young bakers in Denmark (Skjold et al., 2008). Conclusion: There is limited evidence of association between occupational dust exposure and respiratory symptoms among young farmers and bakers in the Nordic countries. However, there are also non-Nordic studies that have found associations between dust exposure in young workers and respiratory conditions such as asthma (De Zotti and Bovenzi 2000; Walusiak et al., 2004).

Occupational noise: Three papers studied the association between occupational noise: one among young professional divers, another among young musician students, and a third among males carrying out their military service. The young divers showed no significant association between noise exposure and hearing deterioration, however there was a mild increase in hearing threshold and a weak reduction in hearing among the young divers (Skogstad et al., 2005). Among the musicians, an association between number of hours of instrumental practice and impaired hearing was found (Hagberg et al., 2005). Occupational noise was reported by over $50 \%$ of males aged 19-22 doing their military service, and an association was found between occupational noise and hearing deterioration (Muhr and Rosenhall 2010). Conclusion: In studies 
based on young workers in the Nordic countries there is limited evidence suggesting an association between occupational noise and impaired hearing. However, for example a recent prospective study from the U.S. found occupational noise exposure to be a risk factor for hearing loss in a cohort of 392 young workers (Marlenga et al., 2012).

Occupational vibration: Two papers studied occupational hand and arm vibration among young workers but they evaluated different outcomes. One cross-sectional paper found association between exposure to occupational vibration and vibrotactile perception among male machine shop workers and construction workers (Gerhardsson et al., 2013). A prospective study by Wahlström and colleagues found an association between daily vibration exposure with duration over 1 hour and neck pain (Wahlström et al., 2008). Conclusion: Based on only two studies, there is limited evidence for an association between physical work factors such as occupational vibration and work-related health in young workers in the Nordic countries.

Mechanical work factors: Ten papers studied mechanical exposures as a possible risk factor among young workers in the Nordic countries. The different papers studied somewhat different aspects of mechanical exposure such as heavy lifting and computer use. The evidence is thus summarized for, repetitive static work and physical demanding work, separately.

Four papers investigated repetitive static workload (three concerned computer use and one musical instrument use). Two papers found no association between computer use and musculoskeletal disorders (Wahlström et al., 2008) or productivity due to musculoskeletal disorders (Boström, 2008). The other two papers however, found associations between repetitive, static workload and musculoskeletal symptoms (Hagberg et al., 2005; Korpinen and Paakkonen 2011). One paper found an association between computer use in leisure time and musculoskeletal symptoms (Korpinen and Paakkonen 2011), and the other found that musician graduate students who practiced 20 hours or more per week had over two times greater incidence of wrist, hand and/or elbow disorders compared to those who practiced less (Hagberg et al., 2005). Conclusion: There are conflicting results, and thus limited evidence for an association between repetitive static workload and musculoskeletal health among young workers in the Nordic countries. 
Six papers addressed physically demanding work as a risk factor for musculoskeletal disorders, three-studied back pain and three studied neck and upper limb symptoms. All three prospective papers on back pain found an association between heavy lifting and physical load among young workers (Laflamme et al., 1997; Mikkonen et al., 2012; Videman et al., 2005). Amongst the papers on upper limb pain, one paper found an association between a high level of sustained trapezius activation during work and neck and shoulder pain (Hanvold et al., 2013). However, the two other studies showed no association between mechanical workload and neck and upper limb pain (Hanvold et al., 2010; Wahlström et al., 2008). Conclusion: There is evidence suggesting an association between heavy lifting and low back pain among young workers in the Nordic countries. This is similar to findings in non-Nordic studies (Merlino et al., 2003; de Zwart et al., 1997). There is insufficient evidence for an association between physically demanding work and upper limb pain among young workers in the Nordic countries.

Psychosocial work factors: Nine papers studied psychosocial work factors among young workers in the Nordic countries. Two of the nine papers studied the association between psychosocial workload and musculoskeletal symptoms. One prospective paper found that psychosocial factors were associated with musculoskeletal symptoms (Khatun et al., 2004). Another prospective paper found that decreased job control and increased negative influence of job demand on private life was a risk factor for reduced workability due to musculoskeletal disorders (Boström et al., 2012). Seven papers studied psychosocial work factors as a risk factor for mental health (e.g. exhaustion, burnout and suicidal ideation). One prospective paper showed that job stress among junior doctors was associated with mental health (Tyssen et al., 2000), while another prospective paper showed that a positive learning climate was a preventive factor for exhaustion among junior doctors (Dahlin et al., 2010). It has also been found that job stress among junior doctors was associated with the learning climate (Tyssen et al., 2005). Another study identified job demands as a risk factor for burnout among newly educated teachers (Hultell and Gustavsson 2011), while low levels of job performance were associated with early career burnout among young nurses in a cross-sectional paper (Gustavsson et al., 2010). No association was found between medical school stress and mental health in the first years of working as a junior doctor (Tyssen et al., 2001b). Likewise, no association was found when studying the association between job stress and postgraduate suicide ideation among junior doctors (Tyssen et al., 
2001a). Conclusion: There is evidence suggesting an association between psychosocial work factors and musculoskeletal symptoms and mental health among young workers in the Nordic countries.

Interventions: Three papers had an experimental intervention design. One study evaluated the effect of special training in skin protection among hairdressing apprentices (Bregnhøj et al., 2012), while another evaluated the effect of an educational program on skin protection among nursing auxiliary students (Held et al., 2001). They both showed positive effects on the development of skin reactions and hand eczema. Svensson et al (2009), evaluated the effect of a low back prevention program among female nursing assistant students, and found no significant difference in the prevalence of low back pain between the two groups (Svensson et al., 2009). Conclusion: There is evidence suggesting a possible effect of an educational skin protection program on skin reactions and hand eczema among young workers in the Nordic countries. There is insufficient evidence of the effect of a low back prevention program on musculoskeletal symptoms among young workers in the Nordic countries.

\subsubsection{Work participation}

Ten of the 32 papers addressing low work participation among young adults were from Norway, and ten from Sweden. Five papers included populations from all five Nordic countries, and one was based on three Scandinavian countries (DK, NO, SE). Three papers were based on a population in Finland and one with populations in both Sweden and Finland. There were two papers based on data from Denmark, while no papers had data from Iceland alone. Most of the papers (8 of 28) studied young adults aged 18-24. There was however also large variations in the age groups studied (i.e. 16-19, 20-24, 21-30, 20-29 and 18-35). The study design, methodological quality and the risk factors studied in each paper are listed in Table 7. The 32 papers studied return to work, intention to leave profession, work satisfaction, inclusion in working life, labor market status, re-employment and employment preparedness. 


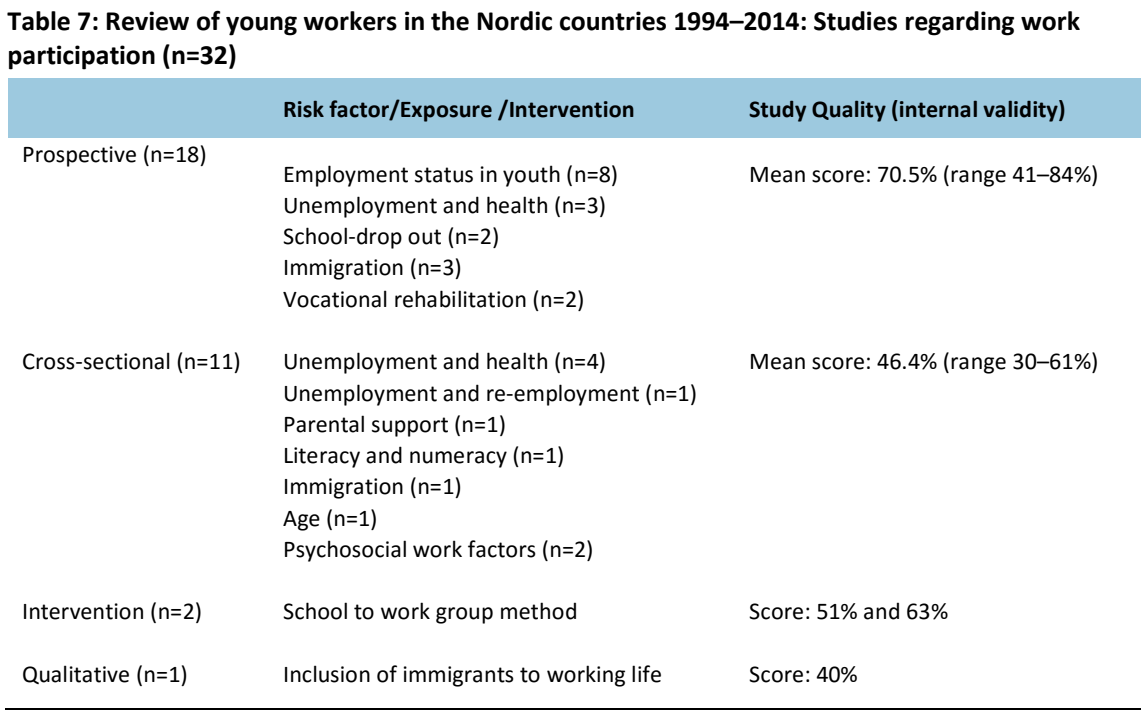

\section{Summary of associations}

Gender: Six papers presented differences in gender when studying low work participation. One paper showed that young men had a higher level of return to work compared to young women, after completing vocational rehabilitation (Ahlgren and Hammarstrom 1999). Another paper showed that young unemployed women had a higher probability of reentering education, compared to unemployed men (Hammer 2003). In another study among those who had experienced earlier unemployment, the relative risk of being unemployed was 2.4 for young men and 1.8 among young women (Hammarström 2000). Additionally, the quality of life among young unemployed men was higher than among unemployed women (Hultman and Hemlin 2008). Women's labor marked status was also found to be more associated with family related variables compared to males (Nilsen et al., 2000). When studying gender differences and low work participation among minority nationalities, it was found that female 2nd generation immigrants did better in obtaining education than males, however they faced greater challenges in the labor market (Nielsen et al., 2003). Conclusion: There is insufficient evidence of a gender difference in work participation among young workers in the Nordic countries.

Ethnic minorities: Six papers have studied minority populations and its association with work participation. Four of the papers find that being a minority is a risk factor for low work participation. Støren and colleagues (2011) found that ethnic minority youth do not have the same probability of being employed as the ethnic majority youth with the same competence and grade level (Støren 2011). Another paper found that 2nd 
generation immigrants are less likely to obtain quality education and that the waiting time for the first job is longer compared to native youth (Nielsen et al., 2003). Yet another study found that long term unemployed immigrant youth had poorer chances for employment than Finnish youth, and that long term unemployed immigrant youth had higher levels of mental health problems than Swedish youth (Malmberg-Heimonen 2006). A qualitative study also highlighted that ethnic minority's experience exclusion by employer in recruiting, with fewer callbacks and interviews (Fangen 2012). The labor market consequence of dropping out of school was however comparable between 2 nd generation immigrant and Norwegian youth (Brekke 2014). Conclusion: There is evidence suggesting an association between young ethnic minority workers and low work participation in the Nordic countries.

Self-rated health: A strong association was found between poor selfrated health, school dropout and risk of receiving medical or non-medical benefits (De Ridder et al., 2012). Another study found that self-rated health status had an impact on success with later employment (Hammer 1997). It is also found that young workers had a greater risk of transitioning from work to sickness absence, and from sickness absence to unemployment (Pedersen et al., 2012). Some papers have also studied health among the unemployed and one study found that long-term unemployment has consequences of poor health among young adults, particularly those with few educational recourses (van der Wel 2011). Continuously unemployed youth have also been found to report significantly more psychological distress compared to those in temporary or permanent employment (Bjarnason and Sigurdardottir 2003). In addition, young adults have poorer quality of life when unemployed (Hultman and Hemlin 2008). Transitioning from an unstable labor market position to a stable market position had in one study been found to be health promoting (Reine et al., 2008). There was however, also a study showing no association between the degree of reported mental health and level of unemployment (Hammer 2000), and that active labour market programs did not have any effect on mental health among young adults (Reine et al., 2011). Conclusion: There is evidence of an association between work participation and self-rated health among young workers in the Nordic countries.

Psychosocial work factors: Two papers assessed different workrelated factors associated with low work participation among young workers in the Nordic countries. One study found that work dissatisfaction and burnout were associated with intention of leaving the profession (nursing) (Flinkman et al., 2008). Work satisfaction was 
also found to be associated with control and reward among young workers (Enberg et al., 2010). It is also found that young women had lower work satisfaction than older working women (Enberg et al., 2010). In yet another paper, work motivation was found to be associated with success with later employment (Hammer 1997). Conclusion: There is limited evidence of an association between low work participation and work satisfaction and motivation among young workers in the Nordic countries.

Earlier unemployment: Eight papers had in different ways studying the effects of early unemployment on later work participation among young adults. Five papers found unemployment at an early age to be a risk factor for later unemployment (Hammarström 2000; Hammer 1996; Hammer 1997; Hammer 1999; Hammer 2007). Being economically inactive for long periods was in another study also shown to result in significant problems in obtaining a stable labour-market position. It was found most problematic for those with inactivity for two consecutive years (Franzén and Kassman 2005). In one study social capital increased the probability of reemployment after unemployment in young age (Hammer 2003). Another paper studied the social exclusion of unemployed youth, yet found no evidence of this among the young adults (Hammer 2000). Conclusion: There is evidence suggesting an association between early unemployment and low work participation among young workers in the Nordic countries.

School dropout: Four papers studied the association between school drop-out/education and later work participation. Two papers found an association between school dropout and later employment, while one paper showed that the youth who dropped out of school had lower employment probability (Brekke 2014). The other paper showed that dropping out of school was associated with receiving medical or nonmedical benefits later in life (De Ridder et al., 2012). Young people with high education and income however, have lower probability of job exit (Nilsen et al., 2000), while the lack of basic skills (poor functional numeracy and literacy) predicts youth unemployment (Lundetræ et al., 2010). Conclusion: There is evidence suggesting an association between dropping out of school and low work participation among young workers in the Nordic countries.

Interventions: Two Finnish papers presented effects of a school-to-work group method on employment after vocational school. They both found positive effects: one found positive longer-term effects on the employment rate and that the employment better matched the educational and personal goals (Koivisto et al., 2007), while the other paper showed a positive immediate effect on employment preparedness, which, in turn, mediated the beneficial effects of the intervention on employment outcomes 
(Koivisto et al., 2010). The intervention was a School-to-Work Group Method: a 5-day intensive course with a highly structured program and focused on boosting self-efficacy beliefs and inoculation against setbacks. Conclusion: There is evidence that boosting employment preparedness among students of vocational schools results in higher employment rate and better quality jobs among young workers. 



\section{Nordic experiences}

\subsection{Materials and Methods}

The final objective of this report was to gather Nordic experiences on challenges, policy initiatives and possible solutions concerning young workers' health, safety and work participation in the Nordic countries. The comparisons of the Nordic experiences are based on data collected through public information, interviews of representatives from vocational education, researchers and authorities in each the five Nordic countries and on a one day workshop session with invited participants from the Nordic countries.

Semi-structured interviews were carried out with teachers, counselors in vocational education and representatives of the education authority. Project members from each of the Nordic countries (PK, MN, SÓ, TNH and ST) carried out the interviews $(n=19)$ and did thematic analysis. Based on the analysis an English thematic summary was provided to the project group. The text highlighted from the interviews are not direct quotes, but based on the thematic summaries. (The interview guide is included in the accompanying on-line document http://dx.doi.org/10.6027/TN2016-512 and attachments). To provide information of existing policy initiatives with focus on young workers' health, safety and work participation in the Nordic countries, an overview was made by each of the project group members. This overview of activities is not complete, but may nevertheless serve as an inspiration, and be used to compare activities in the different countries and provide opportunities for learning.

The workshop session was held at The National Research Center for Work Environment (NRCWE) in Copenhagen, 19 November 2015, with invited representatives from each Nordic country $(n=32)$. Representatives from authorities, employee organizations, employer organizations, education and research, were present. The workshop was organized using a "learning café method", which is a structured conversational process intended to facilitate open and creative discussions, to generate knowledge and identify solutions to various challenges. The workshop participants moved in groups between a series of tables where they discussed the main 
challenges concerning young workers' safety, health and work participation. Solutions and interventions were also discussed.

\subsection{Results}

\subsubsection{OSH in education}

\section{Denmark}

There are 12 different types of vocational education directions covering 107 specific vocational educations, (changes to the education program in the fall of 2015 are not accounted for in this report). Each of the vocational educations has a basic program (common introduction for all) and a main program (specialisation). The students typically have one third classroom/school teaching and two-thirds trainee placement at a company. In the basic program they have some mandatory modules, one of which is in regards to $\mathrm{OSH}$. It requires a one-week course and the student has to pass a graded exam. There is a general set of goals for this module:

- The student is able to contribute to the efforts to create the best possible working environment through participation in and completion of the workplace risk assessment

- The student is able to reflect on and relate concretely to potential dangers and accidents before the completion of a given task

- The student is able to apply knowledge to prevent illnesses due to work related strain and to prevent accidents, including choosing the appropriate working postures and movements

- The student is able to use the instruction manuals of the workplace in order to prevent work injuries

- The student is able to apply knowledge about the physical, chemical - biological, and psychosocial working environment in order to plan appropriate working processes aiming at preventing strain.

In the main program, some of the vocational educations have additional OSH teaching. On the homepage of the Working Environment Authority, they provide information on how to obtain a good and safe working environment at the vocational schools and emphasise that in order to prevent accidents, it is very important that both students and teachers receive careful instruction and training. 


\section{Finland}

There are 119 study programs leading to 53 different vocational qualifications approved by the Ministry of Education and Culture. The Finnish National Board of Education decides on the competence goals regarding OSH. The aim of vocational education and training (VET) is to improve the skills of the work force, to respond to skills needs of the labor markets and to support lifelong learning. Occupational safety is taught in Finnish vocational schools by the penetration principle; this means that occupational safety issues relating to a certain work task are taught, together with work skills. Vocational education and training provide students with the knowledge of occupational safety regulations, work environment factors, vocational field specific hazards, and the identification of risks. The Board of Education and the Ministry of Education present OSH competence goals. Safety training provides basic information on the work environment and those occupational safety and health hazards, which are common in the workplace.

\section{Iceland}

There are 12 different types of vocational education directions leading to a variety of specific occupations. Almost all vocational education in Iceland is offered at upper secondary level, with school and workplace training combined (Cedefop 2015; Kjartansdóttir 2013). Study programs and the workplace training part vary in length. The ministry of education, science and culture issues a national curriculum and is responsible for the operation of the upper secondary schools. Study programs are subject to the approval of the ministry through the link of the occupational councils, one for each type of vocational education direction (Cedefop 2015). The twelve occupational councils advice the ministry on vocational education, make suggestions on objectives and curricula and how the training should be organized, according to law and regulations from 2008 and 2009. Representatives are from employer organizations, workers' organizations and teachers' organizations. In some professions there are also existing professional advice boards with teachers and professionals aiming for suggestions regarding innovation and development in each profession. New curricula have taken over for many programs within vocational education, where OSH knowledge is to be integrated in the study programs but not in separate courses like before.

\section{Norway}

There are 9 different types of vocational education directions covering 198 specific occupations. They are structured as a $2 \times 2$ module with 2 years in school and 2 years as an apprentice in a company. The Ministry 
of Education and The Education Directorate are both seeking a vocational education and training that is adapted to the needs of the labor market. The Norwegian Vocational Educational Training is based on close cooperation between the stakeholders in the working life and the educational authorities. This cooperation is organized through the Cooperation Council for Vocational Training (Samarbeidsrådet for yrkesopplæring SRY) and the nine professional advice boards (Faglige råd) through vocational training committees at the county level. The Ministry of Education determines the framework for the occupation health and safety education. SRY and the professional advice boards participate in this work. There is no requirement for an independent OSH course but $\mathrm{OSH}$ is integrated in a range of courses.

\section{Sweden}

There are 12 different vocational education programs leading to a variety of specific occupations. Each program has a council with representatives from working life, organizations and authorities. The Swedish National Agency for Education determines the framework for the occupational safety and health education. Up until 2011 "Working environment knowledge" (Arbetsmiljökunskap) was a mandatory course in the curriculum of all vocational programs. In the new curriculum GY2011, there is no longer such a course; OSH knowledge is instead to be integrated in the other courses. There are some OSH goals in a civics course which is included in all upper secondary school programs and there are general level OSH goals in the main curriculum of each vocational program.

\section{Interviews}

In the interviews descriptions are given, illustrating that all five Nordic countries have OSH as an integrated part of their courses in vocational education. This practice of incorporating OSH training into vocational schools has been widely recommended (Palassis et al., 2004). Denmark was the only Nordic country that until recently still had a mandatory one-week OSH course at the start of the vocational education - this was revised in august 2015 - so OSH should now be an integral part of the education process). Even though all the five Nordic countries have specific competence goals for OSH knowledge in the vocational educational programs, there is an inconsistency of emphasis, quality and quantity of the occupational safety and health education, as this is largely influenced by the teacher/school's enthusiasm, experience and available time and resources. 
The teachers receive the general goals for teaching, but there are no standard teaching materials. They each have to find and make their own materials which is very time consuming. The students' OSH knowledge greatly depends on which teachers they've had.

Source: Carpenter teacher.

Getting students to understand the importance of OSH, many students want to learn the trade, and are not so fascinated by safety and health. If it is possible to get them to understand the importance and let them know the consequences, then they might understand it better. It is however not enough, as they also have to be met with the opportunity to practice OSH at the salons in terms of ventilation, glove use, chemical use, materials and tools.

Source: Hairdresser teacher.

The young workers' own perception of their occupational safety and health knowledge shows that the majority had received information on occupational hazards and safety regulations (Sulander et al., 2006; Wendelborg et al., 2014). In some of the interviews with vocational teachers, on the other hand, limited knowledge and awareness of safety and health at work was emphasized. It was however evident that the focus on OSH in the workplace and the safety climate in the company where the young people work, was essential for their risk regarding health and safety. 


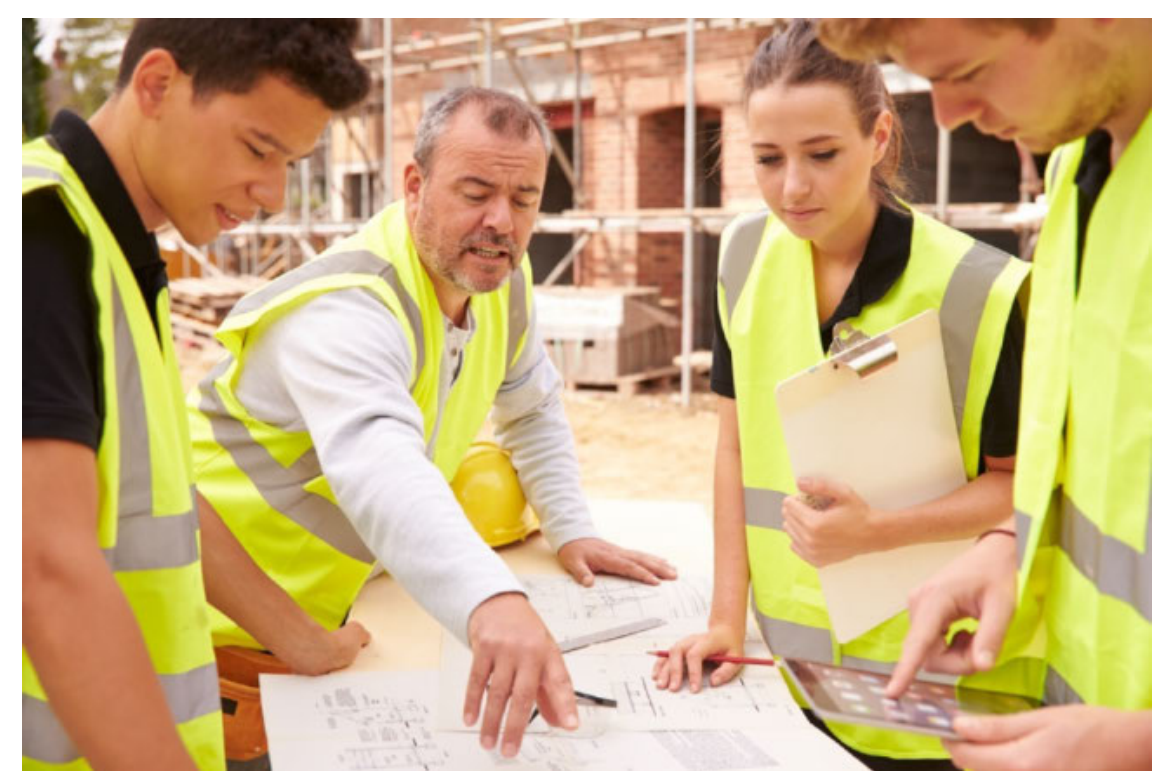

\section{Workshop}

The project's workshop highlighted the importance of avoiding stereotypes and emphasized that the young workers are a heterogeneous group. Furthermore, it was underlined that not all young workers are trained for their work, many of the young workers are in unskilled and temporary work where they often lack experience. One of the challenges highlighted in the workshop was that more focus should be targeted on the workplace. A lack of focus on psychosocial safety, compared to physical safety was also discussed. The need for a broad, holistic view on health and safety was emphasized. Sexual harassment and bullying in the workplace, where the young workers are often highly exposed, was given as an example. The workshop sessions also reflected on the low preparedness for working life among the young workers in the Nordic countries. An understanding and a positive attitude towards $\mathrm{OSH}$ seems to be missing in the education system, from preschool to universities. Finally, treating OSH as a human rights issue was also discussed.

Possible solutions were also proposed, e.g. a closer cooperation between schools and working life was suggested. Starting early and integrating $\mathrm{OSH}$ in the whole educational system was emphasized, i.e. mainstreaming OSH. It was however agreed that OSH in the education system is not enough to secure the health and safety of young workers. 


\subsubsection{OSH at the workplace}

\section{Interviews}

In the interviews with teachers in vocational education some challenges at the workplace were highlighted, e.g. the safety culture the young workers meet at the workplace are important for their exposures to OSH risks.

The school does not have much contact with the companies offering apprenticeships, and very rarely discuss OSH issues with them. Teachers try to get the students to reflect on the way they communicate, and to enter into OSH dialogue with their apprenticeship leaders. Students sometimes come to me during breaks and tell me of unacceptable and hazardous working conditions, and that they are apprehensive of discussing them with their bosses. The students are sometimes told that the company cannot afford, for example technical assistive devices. They have also talked me about how they work with dangerous chemicals without protection, and are shocked when they hear about the health consequences... yet they feel powerless towards bringing it up with their bosses, for fear of negative repercussions.

Source: Carpenter teacher.

Shortage of staff is the main challenge. The students take too much responsibility. Many people without any education are working in hospitals, this imposes increased risk for both patient and student safety.

Source: Nursing assistant teacher.

The knowledge and awareness of OSH is limited. People do not generally understand what is at stake. However, there is more knowledge nowadays than before. In order to improve, increased education is needed, both at the schools and at the workplaces. Prevention is also important, for example using masks to protect the respiratory system, and training how to treat chemicals and various substances.

Source: Carpenter teacher. 


\section{Workshop}

The project's workshop highlighted the importance of incorporating OSH challenges into work organization and work tasks and not focusing solely on the young workers themselves. In the workshop it was suggested to change the perspective from cognitive learning (with focus on the individual) to organizational learning: from the young worker to focusing on the work place, as the young workers are a heterogeneous group of workers. OSH culture was discussed as it varies between companies, particularly in relation to company size. A major challenge is how to transform OSH knowledge and good practice to small companies.

Possible solutions were also proposed and structured OSH introductions, follow up and effective supervision at the workplace were pointed out as important. Supervisor training was also underlined.

\subsubsection{Nordic incentives to enhance OSH}

\section{Denmark}

There are a wide range of initiatives targeted towards young workers' OSH, as outlined in a report from the Danish Working Environment Council (Arbejdsmiljørådet 2015).

"Young at work": (ungmedjob.dk) is a webpage, which provides information and teaching material about the working environment for all levels of schooling including vocational schools. It provides information to parents, teachers, employers, and the young workers themselves about rules and regulations, as well as teaching materials for teachers. It has games to provide a more fun way to learn about the working environment and dilemmas connected to the working environment in work life.

"Erling the apprentice": (Erling the lærling) is a homepage/facebook about young workers' working environment. It primarily provides information about safety issues.

In addition, there are EU-based initiatives, such as: "Prevention through cooperation": European working environment week - in the past few years the focus in Denmark was on young workers. In 2013, a campaign ran for a week where a road show visited 11 vocational schools nationwide and arranged dialog meetings about safety and a better working environment. Representatives from employers, employees, and the Danish Working Environment Authority as well as a stand-up comedian and a group of rappers participated in the events. The campaign was also run in 2014.

"Napo - safety with a smile" is another European campaign that is active in Denmark as well. The campaign consists of a promotional leaflet 
about Napo and animated silent movies on work safety and health. Napo is the character in these movies that function as learning tools about safety and health among people of all ages in various occupations.

\section{Finland}

There are several different initiatives and these are only some examples.

The National Occupational Safety Card. It is a training system developed to enhance occupational safety and health in the shared workplace. The Occupational Safety Card Course (1 day) is held by a course leader who is qualified in a specific trainer training. Those who pass the course and a written exam are granted the Occupational Safety Card, valid for five years. The renewal of the card requires at least four hours of further training. A person who has passed the Occupational Safety Card course has basic knowledge about the cooperation and general hazards of the shared workplace, knowledge about the key principles and good practices of occupational safety and basic readiness to workplace and job orientation. Although the safety card is not based on national legislation and is voluntary, it is often a mandatory part of the skills requirements in vocational education.

"Attitude for work": FIOH has started a new research and development project that aims to support safety behaviour and proactive work behaviour of young people entering working life. During the "Turvapeda 2" campaign, OSH intervention has been implemented in eight large vocational education providers in Finland. "Attitude for work" -intervention aims at enhancing occupational safety and health related preparedness and proactive skills of young people entering working life. The intervention theory applies earlier principles of preventive group methods (Vuori \& Vinokur 2005; Price et al., 1998) and applies active learning methods, such as social modeling, role-playing, brainstorming, group discussions. The intervention consists of a 12-hour group counselling program. The aim is to disseminate this method widely into the Finnish vocational education institutions.

"Zero Accident Forum": FIOH coordinates a national network of companies sharing a common vision of becoming leaders in safety and are willing to share their experiences for the benefit of other members. Over 300 organizations from all over Finland had joined the Forum by August 2013. Altogether, 250 Zero Accident Forum safety level certifications had been granted during 2005-2013. The network is meant for all kinds of workplaces, which are interested in prioritizing occupational safety and are striving to the forefront of safety, are promoting the "vision zero" approach and act in accordance with it. The network provides examples of good practices from other workplaces and promotes success stories. However, 
there is no special focus on young workers. In autumn 2008, a steering group was appointed at National Public Health Institute (since 2009 National Institute for Health and Welfare, THL) and assigned with the task of drafting a national action plan for injury prevention among children and youth and of approving and promoting the action plan in their administrative fields. The action plan actively interlinks different kinds of approaches to injury prevention taking into consideration:

1. The safety of the physical and social environment as well as that of products and services.

2. The legislation and national guidelines that promote and support safety.

3. Safety-related education and upbringing.

\section{Iceland}

There are numerous of initiatives, some are presented here.

"Fact sheets": The Administration of Occupational Safety and Health (http://www.vinnueftirlit.is/english) has published advice on fact sheets to young people, parents and employers regarding $\mathrm{OSH}$.

"School of life": Workers' unions have launched campaigns with the aim of educating young people on their rights and obligations in the beginning of their working life, for example Commercial and office workers' union (VR): School of life (http://www.vrskolilifsins.is) aiming for strengthening young people's position on the labour market.

"Sustainable hairdressing": An example of how OSH is transmitted to the young workers in Iceland is for those studying in upper secondary schools, one fundamental pillar of the education policy in the national curriculum for upper secondary schools is health and welfare, where security is to be encouraged. An example of OSH measures in curricula within vocational education is a focus on environment-friendly substances and sustainability in the main hairdresser study program originating from an international program (http://sustainablehair.eu/ language/en/sustainable-development-in-hairdressing/).

There has also been an increase in research on OSH among young workers and Einarsdóttir and colleagues have found that the prevalence and seriousness of young workers' injuries are of concern, and education and training on OSH is of importance (Einarsdóttir et al., 2014). Einarsdóttir's doctoral thesis has concluded that a tension exists between the economic and physical welfare of young people with regard to paid work. To solve this tension a perspective that recognises children and 
teenagers as active economic participants is needed, nevertheless, they need special protection in the labour market (Einarsdóttir 2014).

\section{Norway}

There is a variety of initiatives in example.

"At the start of working life" - "Ny i arbeidslivet". The Labour Inspection Authority strategic plan for 2008-2012 has as an objective that young workers and their employers should have knowledge of the social rules and key conditions for a good working environment. This is a prerequisite for getting a good start in working life, prevent exclusion and establish a preventive culture in future generations and better working practices in the long term. One of the Labour Inspection strategies for the period 2013-2016, is to spread knowledge to companies with many young workers and emerging businesses about their rights, duties and what creates a good working environment through the initiative.

"A manual for regional safety deputies within construction": A manual called "prevention of accidents among young workers" is targeted towards regional safety deputies. Regional safety deputies are visiting companies and especially small companies and this manual give advice in how to talk to young workers as well as focus areas when talking to management about young workers. The Manual has been prepared as part of the project "Young workers in building \& construction - from school to employment", where the International Research Institute of Stavanger (IRIS) has had project management.

"Information to instructors in teaching businesses": Another example is information materials called "Systematic training of our future workers" prepared by the Directorate of Education for participants in vocational education and training and instructors in teaching businesses. They have created six special issues with integrated focus on OSH.

\section{Sweden}

Here are examples of initatives targeted to young workers in Sweden.

"Focused inspections": In the summer months, the Swedish Work Environment Authority inspects typical temporary jobs for youths. Ongoing since 2011.

"Summer campaign": The Swedish Trade Union LO has a summer campaign with focus on temporary jobs for young, with information about rights and demands in working life.

"The step into working life": (Klivet in i arbetslivet). PREVENT - a collaboration for the working environment by employer and worker organizations, has produced information material about work place introduction, including $\mathrm{OSH}$. 
"Web-based supervisor training": The National Education Agency has produced introductory education and training material for supervisors in work places and vocational schools, which is web-based and free to use.

"Healthy vocational start": (Hälsosam yrkesdebut) is a project concerning charting, assessment and proposed actions for upper secondary schools; "medical vocational guidance" in schools in Stockholm County (http://camm.sll.se/var-verksamhet/projekt/halsosam-yrkesdebut/)

"Introducing youth to working life" is a research project at Dalarna University where the collaboration between the vocational schools and the workplaces concerning OSH is highlighted.

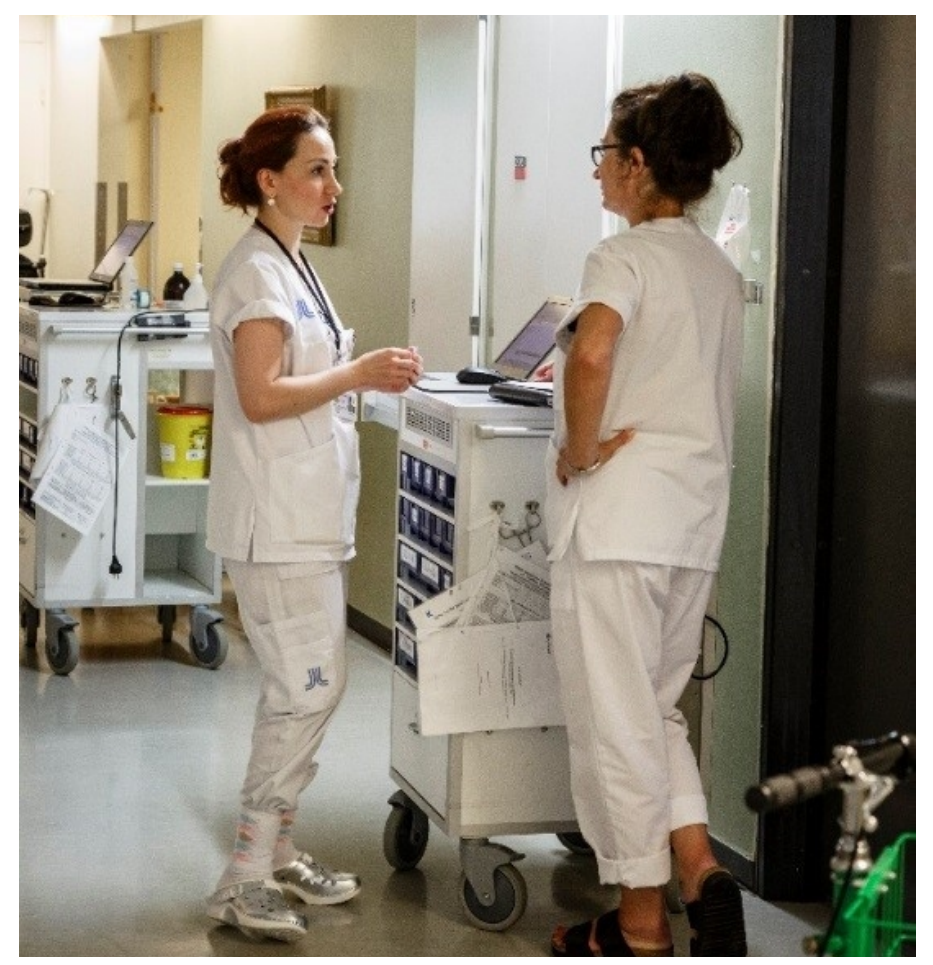

\subsubsection{Work participation - Transition from school to work}

\section{Interviews}

The interviews with educational counselors and teachers in vocational education highlighted some challenges in terms of increasing work participation among young people in the Nordic countries. Receiving an apprenticeship was emphasized as important to increase work participation. This requires a systematic collaboration between school and companies.

There are differences in the upper secondary vocational education in the Nordic countries. Finland and Sweden offer mainly school based 
vocational training programs, while Denmark, Iceland and Norway offer apprenticeship training linked to a regulated system for the trade (Olofsson and Wadensjö, 2012). This may influence the transition from vocational school to working life.

To get young workers included in working life it is important to give them a good start, and to help them get their first job (apprenticeship). Good collaboration between the school and the workplaces is essential. Giving them the belief in themselves is also important.

Source: School guidance counsellor.

It is important to adjust to individual needs, and that the schools have the right prerequisites to do that. Apprenticeship is a possibility for some. Completing secondary school is a success factor. Students who have had apprenticeship at workplaces are more likely to enter the labor market. Even if the difference is small, the apprentices probably can enter working life more easily.

Source: Head of vocational education.

Schools have many projects that aim to prevent dropout. For example, "Passing the education more efficiently" - program has been undertaken to expedite study times in vocational education and training, to reduce dropout and to support progress in studies and qualification in the target time. The program will especially support the development of anticipatory and person-centered procedures in guidance counseling, pedagogical solutions supporting the completion of studies, practices and action models in guidance counseling, and various work-centered learning environments and opportunities, for example integration of theoretical studies into practical learning environments. In addition, there should be more emphasis on developing the life management skills of students.

Source: School guidance counsellor. 


\section{Workshop}

The project's workshop highlighted the importance of taking into account the more unsecure employment environment. Low work participation among people with disabilities was emphasized. Learning difficulties was also discussed in relation to vocational school and the possibility for a less theoretical approach and more practical approach.

Low preparedness for work life among young workers and challenges related to ethnic minorities and their possibilities of work participation was discussed.

In the workshop possible solutions were also proposed and decreasing stigma related to disabilities, especially mental health disabilities was underlined. In terms of learning difficulties more concrete training methods and apprenticeships were proposed. Some good examples from the Nordic countries were presented.

\subsubsection{Nordic incentives to enhance work participation}

\section{Denmark}

"Job Centres": coordinated municipal "Job Centres". The incentives aimed at young people have been given priority under a comprehensive "employment strategy aimed at young people". Emphasis is placed on early incentives, close follow-up and mutual demands and expectations between young people and the job centres.

"Practice packages": Education and inclusion in employment through vocational/occupational studies are also a priority.

\section{Finland}

"Youth Guarantee": The Youth Guarantee is a societal guarantee for young people where the Finnish government guarantees that unemployed youth under the age 25 and graduated under 30 year old youth will get a job, training or other supportive actions within 3 months. Thís guarantee was implemented in 2013 to prevent long-term unemployment and inactivity among young people.

"The School-to-Work Group method": FIOH has developed group methods for supporting the transitions from basic education to secondary studies and from vocational education to work. Related with this developmental work FIOH has conducted intervention studies targeted at these transition phases of young people. Towards-working-life and School-to-work interventions have been developed for promoting career choice, employment and mental health among young people entering the work life. The aim is to promote active role and needed critical skills 
during the two different transition processes towards the labor markets, respectively. The School-to-Work Group Method is the English version of the method and is available at http://www.ttl.fi/en/working_career/ youth/Pages/default.aspx

"Into Working life" is a website (http://tyoelamaan.fi/) with information services targeted especially at young workers, includes information about job-searching etc.

\section{Iceland}

Young people's work participation is high in Iceland, nevertheless there are some initiatives to increase work participation further. Among the goals in a new report from the Ministry of welfare on organising working life in Iceland (2015) is to decrease dropout from upper secondary school and increase access to the labour market for the group 20-30 years.

"Skills beyond School": Iceland was a part of the project Skills beyond schools - the OECD policy review of postsecondary vocational education and training, which looks at the preparation of younger people and adults for technical and professional jobs. The National Background Report for Iceland, recommended for example paying an increased attention to students' interests, experience and background when planning vocational education and training (Kjartansdóttir 2013). Among the main challenges recognized in the Commentary on Iceland (Musset \& Castaneda Valle 2013) was dropout, particularly affecting vocational programs.

"Education is a working way": During the years 2011-2014 the Ministries of education and welfare hosted the campaign Education is a working way (Icelandic: Nám er vinnandi vegur) with the objective to fight dropout and unemployment among young people. The project was partly based on suggestions from students' associations. Part of the project was increasing funds to workplace education.

\section{Norway}

"Business in school": (Næringsliv i skolen) is NHO's (The Confederation of Norwegian Enterprise) focus on partnerships between schools and businesses. Students, teachers and employees of companies and organizations benefit greatly from partnership agreements. The goal is to help learners gain greater insight of the role of business as a value creator and a better basis for occupational and educational choices.

"Campaign apprentice company": (Aksjon lærebedrift) The Norwegian Confederation of Trade Unions (LO) and The Confederation of Norwegian Enterprise (NHO) have received support from various counties to start up the project campaign apprentice company. The project aims to increase the number of approved apprenticeships, increasing the number of adults 
taking a "svenneprøve" and to increase the number of students who complete and pass a craft or journeyman's certificate. The project will use the NHO and LO networks to recruit several training companies

"Fresh start": (Ny giv) In 2011 the Ministry of Education initiated a nationwide project entitled Fresh start. It is designed to prevent and reduce the drop-out from vocational school. One of the most comprehensive measures is intensive training in reading, writing and arithmetic for students with the weakest academic level in tenth grade. The project finished in 2013.

"Youth Guarantee": The Norwegian government has initiated the Youth Guarantees which are arrangements to prevent long-term unemployment and inactivity among young people. The guarantee scheme is aimed at young people who have a real need to get into work. Young people with decisions about the need for situational efforts to have an approved activity plan within one month after they have received a follow-up resolution from the NAV office.

\section{Sweden}

"Job Guarantee for Young People" is an important initiative designed to increase youth employment rate. It is an incentive through the Swedish Employment Agency, aimed at individual identification, guidance, work practice, training and education of unemployed youths (16-24 years).

"Vocational Introduction Employment" is another incentive, with government grants to employ youths (15-24 years) without work experience or who have been unemployed more than 3 months. The employment includes at least $15 \%$ education or supervision.

"New Start Job" is a more general labour market program in which wage subsidies are an important feature. One of the measures introduced has involved reducing employers' National Insurance contributions in order to encourage employment among young people.

"Theme Group Young People in Working Life" is a collaboration between the Swedish Employment Agency and several authorities and organizations, granted from the European Social Fund. The theme group gathers and disseminates knowledge about young people not in education or employment (NEETs).

"Youth integration" (Unga in). The Employment Agency had a project to actively identify and reach out to the NEETs, and produced the report "Young people in and outside the labour market". 


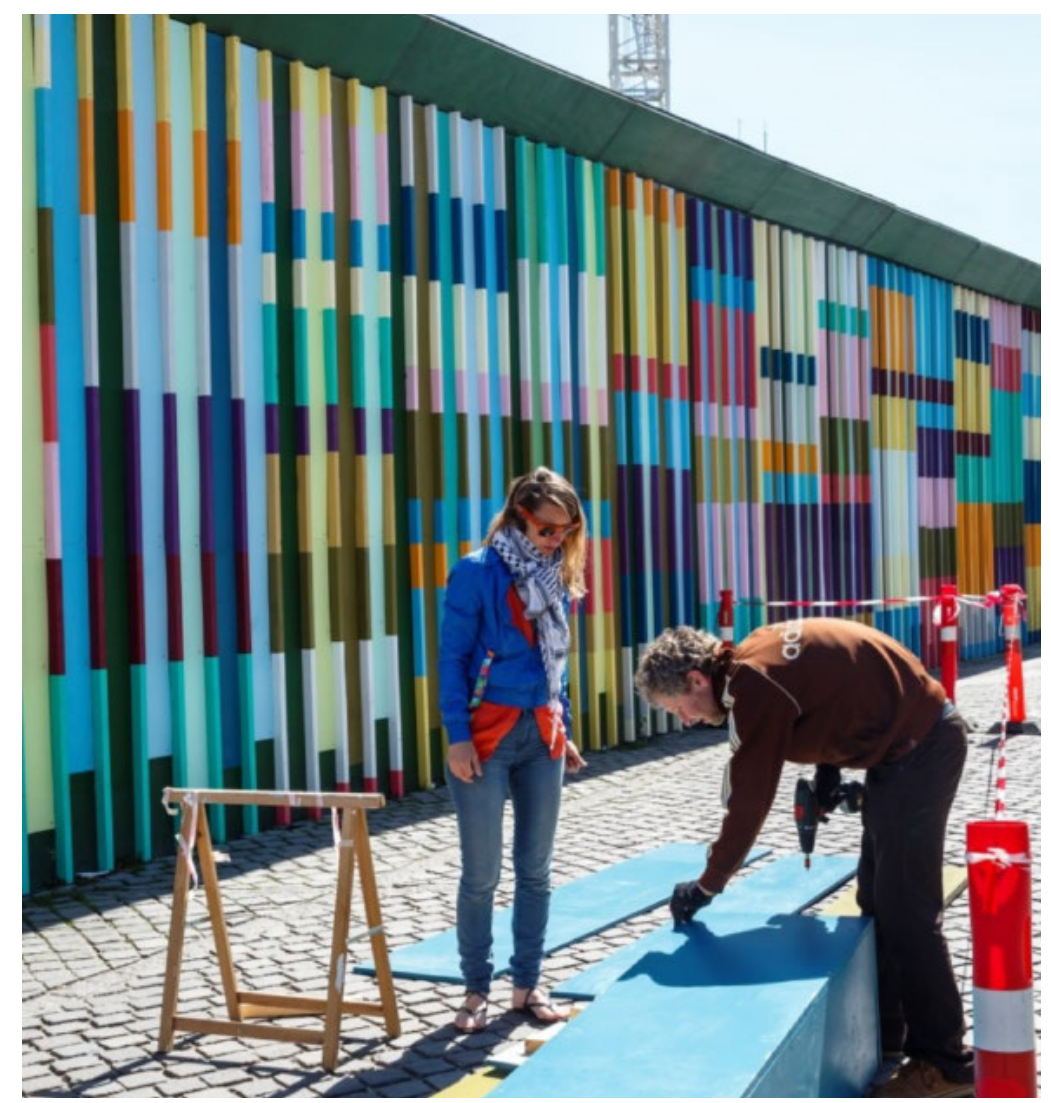





\section{Discussion}

\subsection{Summary of results}

Table 8 provides a concise summary of the results on work-related health and accidents, as well as work participation.

Table 8: Summary of results

\begin{tabular}{|c|c|c|c|}
\hline & Statistics * & Review & Interview/Workshop \\
\hline \multicolumn{4}{|l|}{ Work-related health } \\
\hline & $\begin{array}{l}\uparrow \text { Physical demanding work } \\
\uparrow \text { Sexual harassment/ } \\
\text { bullying } \\
\uparrow \text { Mental health problems } \\
\uparrow \text { Headache } \\
\uparrow \text { Skin problems } \\
\uparrow \text { Chemical exposure }\end{array}$ & $\begin{array}{l}\text { Handling heavy loads } \\
\text { Work distress } \\
\text { Occupational noise } \\
\text { Chemical exposure }\end{array}$ & $\begin{array}{l}\text { OSH at the workplace } \\
\text { (Safety culture) } \\
\text { Limited knowledge } \\
\text { Lack of standardized OSH } \\
\text { education } \\
\text { Sexual harassment/ } \\
\text { bullying }\end{array}$ \\
\hline \multicolumn{4}{|l|}{$\begin{array}{l}\text { Occupational } \\
\text { accidents }\end{array}$} \\
\hline & $\begin{array}{l}\text { } \text { Accidents at work among } \\
\text { young workers } \\
\uparrow \text { Accidents at work in } \\
\text { farming, forestry, fishing } \\
\text { and construction }\end{array}$ & $\begin{array}{l}\text { Safety climate at work } \\
\text { Male gender } \\
\text { Mechanical workload } \\
\text { Psychosocial work } \\
\text { demands }\end{array}$ & $\begin{array}{l}\text { OSH at the workplace } \\
\text { (Safety culture) } \\
\text { Limited knowledge } \\
\text { Lack of standardized OSH } \\
\text { education } \\
\text { Lack of safety introduction, } \\
\text { training and supervision at } \\
\text { the workplace }\end{array}$ \\
\hline \multicolumn{4}{|l|}{ Work participation } \\
\hline & $\begin{array}{l}\uparrow \text { Temporary work } \\
\uparrow \text { Shift work and atypical } \\
\text { work hours }\end{array}$ & $\begin{array}{l}\text { Ethnic minorities } \\
\text { Earlier unemployment } \\
\text { Self-rated health } \\
\text { School-drop out }\end{array}$ & $\begin{array}{l}\text { Low preparedness for } \\
\text { work life } \\
\text { Lack of collaboration } \\
\text { between education and } \\
\text { companies }\end{array}$ \\
\hline
\end{tabular}

Note: Arrows pointing up, means that there is a higher frequency among young workers compared with older workers.

It is evident from the results of the current report that there is a need for an inter-disciplinary and comprehensive approach to ensure a sustainable work life among young workers. The six factors presented in the introduction of this report may all contribute in different ways to a sustainable work life by increasing occupational safety, health and work participation among young workers (characteristics of the worker, youth, education, workplace, employment and work task). 


\subsection{Youth and worker characteristics}

The characteristics of the young workers are important both when it comes to work participation and also when discussing occupational safety and health. Young workers are traditionally perceived as a vulnerable group as they are inexperienced and have low preparedness for work life. These factors need to be understood in the context of the transition process from "youth to adulthood", and "school to work". The current report found a paper showing that motivated young workers had higher success with later employment (Hammer, 1997). Another important psychosocial aspect regarding young worker's careers and work participation is their preparedness for managing their own careers. Young people often experience difficulties and setbacks when starting their working careers. Skills-mismatch is one troubled aspect of working conditions of young workers. Young workers may be "skill-underemployed" which means that their jobs do not afford them the opportunity to put their skills and training to use. On the other hand, work can be too demanding as young workers do not yet have sufficient professional skills. In addition, young workers are increasingly facing employment that is parttime or temporary.

Preparedness for career management includes career self-efficacy (Bandura, 1986) with the confidence to implement the actions required to acquire and maintain work-related goals, and preparation against possible setbacks that young workers may encounter during their career. Preparation against setbacks refers to anticipatory stress management skills that help employees to maintain active behavior and well-being when faced with career setbacks and barriers. Preparedness is an important aspect related to job attendance of young workers (Koivisto et al., 2007). Other factors which have been evaluated as important are loyalty and commitment to a work or an organization. A three-component model has been proposed for commitment to an organization; 1) the affective component refers to a workers' emotional attachment, 2) the continuance component is associated to the costs by leaving it, and 3) the normative component refers to the workers' obligation to stay (Allen and Meyer, 1990). These components have been investigated in relation to commitment to work, or to a specific organization and have been negatively associated with e.g. turn-over rates (Cohen, 1993; CooperHakim and Viswesvaran, 2005) and work absence (Bakker et al., 2003). Young technical professionals associate high commitment to an organization with good work-life balance, but not to job-security compared with older professionals (Finegold et al., 2002). 
Young workers are also traditionally perceived as a vulnerable group as they are inexperienced and lack training as well as OSH risk awareness and perception. These factors also need to be understood in the context of the transition process from "youth to adulthood," and that the risk socialization process young people are undergoing as they enter the job market. This emphasis the importance of targeting the workplace were the young workers enter.

\subsection{Educational characteristics}

The current report has shown that even though there are clear OSH goals in all vocational schools in the five Nordic countries there is a lack of standardized occupational safety and health education in schools. The quality and quantity of OSH education is often dependent on the school or the individual teacher. This results in a varied OSH knowledge among the young workers entering working life. There are also many young workers in unskilled work and have no OSH education at all. This means that the OSH training largely depends on the workplace. A good example here would be the Zero accident vision study (Zwetsloot et al., 2015), where safety is an integrated part of doing business, and not an independent activity. This aspect is particularly transferable to schools, where teachers and young people could learn to have a focus on OSH in their everyday school and work activities - before entering work life.

The current report also identifies challenges regarding low preparedness for work life among young workers in the Nordic countries. Preparedness is related to wellbeing and mental health during transition from education to working life, and therefore it is an important aspect related to job attendance of young workers (Koivisto et al., 2007). In the literature review of this report two intervention studies were found on employment preparedness and factual employment after vocational school (Koivisto et al., 2007; Koivisto et al., 2010). The School-to-Work Group Method is a 5-day intensive course with highly structured program and focuses on boosting self-efficacy beliefs. The proximal effect of the intervention showed a significant increase in employment preparedness, which in the long-term follow-up resulted in higher employment rate and better quality employment compared to controls. Both of these studies demonstrated results that have been found in other studies with other participant populations (Vinokur et al., 1995; Vuori et al., 2005; Vuori et al., 2002; Vuori et al., 2012). 


\subsection{Workplace characteristics}

In the current report, it is underlined that both OSH introduction and safety culture at the workplace have to be considered to ensure young workers OSH. How the different companies organize OSH introduction, training and supervision is central, and this may be influenced by different factors, e.g. company size may have an effect on the amount of resources and ways in which OSH is organized. There should therefore be increased emphasis on OSH in small enterprises. In the working situation the young workers have to adjust to the safety culture at the workplace, and this makes the workplace characteristics important when it comes to young workers' health and safety. Adapting a "zero vision commitment strategy" has been proposed. The Finnish "Zero accident forum" entails employers and employees having mutual commitment to prevent all accidents. We refer to the report on young workers' occupational safety and health risk in the Nordic countries from 2013, where they boldly suggested adapting a "zero vision commitment strategy" for young workers in the Nordic countries. Good practices in this regard have recently been proposed by researchers in the Partnership for European Research in Occupational Safety and Health (PEROSH), in a study involving 27 companies in Europe with a "Zero Accident Vision" (Zwetsloot 2015). In comparison to traditional accident prevention the ZAV approach is focuses on "creating safety" rather than "preventing accidents", it is about "safety leadership" rather than "safety management", focusing on "people" and "culture" and not just "systems". Likewise, safety is an integrated part of doing business, and not an independent activity.

\subsection{Employment characteristics}

Labour marked attachment such as atypical work hours are of importance when discussing a sustainable work life. This report shows that young workers in the Nordic countries are at higher risk of having temporary employment and working shift or atypical work hours. Atypical working hours have been found to be associated with health problems. Based on a meta-analysis of the literature it was found that temporary employment gave great uncertainty with regard to the work duration and work content (Virtanen et al., 2005). It also resulted in an increased risk of health problems (Virtanen et al., 2005). Uncertain income, poorer training opportunities as well as exposure to other working conditions, exposures 
are believed to contribute to poorer health and accidents among the temporary employees.

\subsection{Work task characteristics}

Young workers in the Nordic countries are exposed to handling heavy loads, chemical exposures and work distress at an early age and to a larger degree than their older colleagues. In contrast to occupational injuries, young workers have been found to have lower risk of developing workrelated disorders than older workers (Laflamme et al., 1997; Taimela et al., 2007). However most occupational diseases need cumulative risk exposure and have a latency period to develop, and there are very few studies tracking the effect of risk exposure for young workers. Handling heavy loads is an example of a work task that has high prevalence among young workers. It has also been associated with both work-related health and occupational accidents among both young and older workers. This might suggest that young workers are at a greater risk because of the work tasks they are assigned to do. A possible approach to level out or reduce high risk exposure for young workers may be to promote organizational and cultural changes that contribute to increased training and supervision, and to better distribute the high risk tasks based on level of experience. 



\section{Conclusions and recommendations}

This report underlines the importance of taking into account the characteristics of the young workers, the workplace, the work task, the education and the employment in an attempt to increase our understanding of young workers' health, safety and work participation.

\subsection{Ensuring systematic education, introduction, training and supervision in occupational safety and health}

The report has identified some common challenges with regards to OSH among young workers in the Nordic countries. One of these challenges is the lack of systematic OSH education in vocational schools. The importance of introduction, training and supervision at the workplace was also strongly emphasized as a challenge. These are important aspects to consider as OSH introduction, training and supervision play an important role in strengthening prevention culture in workplaces. The need to ensure systematic OSH education, particularly in vocational schools, may be vital to increase OSH knowledge among young workers in the Nordic countries. Improved and better funded collaboration between educational institutions and enterprises is necessary to facilitate a safe and participative transition from school to work life. As young workers are such a heterogeneous group it may also be important to differentiate between specific categories of young workers to give a more customized approach. Skilled workers (from vocational schools) and unskilled workers are examples of groups that can be very different in terms of OSH risk and OSH knowledge. Young workers in construction versus young workers in the retail industry is another example. 


\subsection{Secure and transfer effective initiatives}

There are several examples of initiatives and projects from all five Nordic countries targeting young workers. However, very few of these initiatives have been evaluated properly. How effective are they, and do they reach the young workers in their daily life? Some of the initiatives are evaluated and show positive effects, one of them from Finland where FIOH has carried out several campaigns related to interventions that support the participation of young people in working life. Projects have been carried out in collaboration with educational institutions and workplaces. The campaign activity "Towards-working-life" and "School-to-work" interventions have been disseminated and practiced widely in Finland. FIOH provides training of group trainers, and distributes method publications. For example, since the publication of the "School-to-Work" method in 2002, over 500 teachers and other persons have been trained to become trainers of the group method, and over 17,500 participant workbooks have been distributed in Finland. This method may also lead to positive effects if transferred to other Nordic countries. It is however of importance to evaluate the initiatives that are targeted to young workers' health, safety and participation, to be able to secure and transfer the initiatives that are effective.

This report proposes that having closer Nordic cooperation on these issues could have considerable benefits. A better knowledge base is important in order to implement effective initiatives and learning from experiences from the other Nordic countries. One way to transfer effective initiatives and to share ideas and knowledge about young workers' health, safety and work participation is by creating a "Nordic idea bank". This is a concept that is used in Norway by providing information and sharing ideas on sick leave, senior policy and inclusion, www.idebanken.org.

\subsection{Improving research regarding young workers}

The report identifies that young male manual workers in the Nordic countries have a high risk of non-fatal occupational accidents. An enormous amount of register based descriptive data have been published regarding young workers and occupational accidents and injuries. There is however a need for more explorative and analytic studies on occupational accidents among young workers. There is also a lack of studies with an experimental design, assessing the efficiency of different interventions in increasing young workers' OSH. An increase in facilitating experimental research is 
therefore recommended. These could be population-based or individualbased intervention studies.

The majority of the literature on work-related health deals with middle-aged or older workers. It is evident from this report that there is a need for more studies with a specific focus on young workers, and not just as a part of a larger cohort. It is also evident that there are some occupations more often studied than others, such as junior doctors, farmers and hairdressers. There is therefore a need for more studies with populations from a wider variety of occupations, where young workers are employed, e.g. within retail, hotel, construction, transport and the service sector. It is at the same time evident to emphasize that young workers comprise a heterogeneous group, and that their vulnerabilities to occupational health risks are highly contextual. This means that research should try to capture this complexity when identifying risk factors or initiating interventions among young workers.

An increased focus on the importance of young workers' transition and participation into working life has led to a large number of reports with this focus. It is however evident from this report that there is a need for more scientific research to increase the understanding of young workers' work participation. There is still a need for discussions concerning how to define work participation, and how to measure outcomes so that they are comparable between studies.

Finally, much of the research in this field focuses on young workers from their own perspective. There is a need for increased knowledge of young workers' OSH from the perspective of the managers and employers. Moreover, how they can be more effective in ensuring a sustainable work life for a multinational workforce of young workers. 



\section{References}

Ahlgren, C \& Hammarström, A. (1999). Has increased focus on vocational rehabilitation led to an increase in young employees' return to work after workrelated disorders? Scand J Public Healt 27(3):220-227 http://dx.doi.org/10.1177/ 14034948990270030101

Allen, N.J. \& Meyer, J.P. (1990). The Measurement and Antecedents of Affective, Continuance and Normative Commitment to the Organization.J Occup Psychol 63(1):1-18. http://dx.doi.org/10.1111/j.2044-8325.1990.tb00506.x

Arbejdsmiljørådet (2015). Årlig status for børn og unges arbejdsmiljø 2014/2015. Copenhagen, Denmark.

Arbetsmiljöverket (2014). Arbetsskador 2013 Occupational accidents and workrelated diseases. vol 1. Arbetsmiljöverket.

Bakker, A.B., Demerouti, E., de Boer, E., \& Schaufeli, W.B. (2003). Job demands and job resources as predictors of absence duration and frequency.J Vocat Behav 62(2):341-356. http://dx.doi.org/10.1016/S0001-8791(02)00030-1

Bandura, A. (1986). The explanatory and predictive scope of self-efficacy theory. Journal of Clinical and Social Psychology 4:359-373. http://dx.doi.org/10.1521/ jscp.1986.4.3.359

Bank of the World (2015). GDP per capita. Accessed 15 August 2015 http://data.worldbank.org/indicator/NY.GDP.PCAP.CD/countries?order=wbapi_da ta_value_2013+wbapi_data_value+wbapi_data_value-last\&sort=desc

Bjarnason, T. \& Sigurdardottir, T.J. (2003). Psychological distress during unemployment and beyond: social support and material deprivation among youth in six northern European countries. Soc Sci Med 56(5):973-985. (doi:Pii S02779536(02)00109-0) http://dx.doi.org/10.1016/S0277-9536(02)00109-0

Boström, M., Dellve, L., Thomée, S., \& Hagberg, M. (2008). Risk factors for generally reduced productivity - a prospective cohort study of young adults with neck or upperextremity musculoskeletal symptoms. Scand J Work Environ Health 34(2):120-132. http://dx.doi.org/10.5271/sjweh.1218

Boström, M., Sluiter, J.K., Hagberg, M. (2012). Changes in work situation and work ability in young female and male workers. A prospective cohort study. BMC Public Health 12:694. http://dx.doi.org/10.1186/1471-2458-12-694

Bregnhøj, A., Menne, T., Johansen, J.D., \& Sosted, H. (2012). Prevention of hand eczema among Danish hairdressing apprentices: an intervention study. Occupational and Environmental Medicine 69(5):310-316. http://dx.doi.org/10.1136/ oemed-2011-100294

Bregnhøj, A., Sosted, H., Menne, T., \& Johansen, J.D. (2011a). Healthy worker effect in hairdressing apprentices. Contact Dermatitis 64(2):80-84. http://dx.doi.org/10.1136/oemed-2011-100294

Bregnhøj, A., Sosted, H., Menne, T., \& Johansen, J.D. (2011b). Exposures and reactions to allergens among hairdressing apprentices and matched controls. Contact Dermatitis 64(2):85-89. http://dx.doi.org/10.1111/j.1600-0536.2010.01843.x 
Brekke, I. (2014). Long-term labour market consequences of dropping out of upper secondary school: Minority disadvantages? Acta Sociol 57(1):25-39.

http://dx.doi.org/10.1177/0001699313495056

Breslin, F.C., et al. (2005). Systematic review of risk factors for work injury among youth. Toronto: Institute for Work \& Health.

Bull, N., Høvding, G., Riise, T., \& Moen, E.B. (2004). Kan arbeidsrelaterte øyeskader unngås? Tidskr Nor Lægeforen 21:2776-9.

Bull, N., Riise, T., \& Moen B,E, (1999). Occupational injuries reported to insurance companies in Norway from 1991 to 1996. J Occup Environ Med 41(9):788-793. http://dx.doi.org/10.1097/00043764-199909000-00010

Bull, N., Riise, T., \& Moen, B.E. (2001). Occupational injuries to fisheries workers in Norway reported to insurance companies from 1991 to 1996. Occup Med (Lond) 51(5):299-304. http://dx.doi.org/10.1093/occmed/51.5.299

Cedefop (2015). Spotlight on VET - Anniversary edition. Vocational education and training systems in Europe Cedefop information series. Luxembourg: Publications Office of the European Union.

Cohen, A. (1993). Organizational Commitment and Turnover - a Metaanalysis. Acad Manage J 36(5):1140-1157. http://dx.doi.org/10.2307/256650

Cooper-Hakim, A. \& Viswesvaran C (2005). The construct of work commitment: testing an integrative framework. Psychol Bull 131(2):241-59. http://dx.doi.org/ 10.1037/0033-2909.131.2.241

Dahlin, M., Fjell, J., \& Runeson, B. (2010). Factors at medical school and work related to exhaustion among physicians in their first postgraduate year. Nord J Psychiatry 64(6):402-8. http://dx.doi.org/10.3109/08039481003759219

De Ridder, K.A.A., Pape, K., Johnsen, R., Westin, S., Holmen, T.L., \& Bjørngaard, J.H. (2012). School dropout: a major public health challenge: a 10-year prospective study on medical and non-medical social insurance benefits in young adulthood, the Young-HUNT 1 Study (Norway). J Epidemiol Community Health 66(11):9951000. http://dx.doi.org/10.1136/jech-2011-200047

De Zotti, R. \& Bovenzi, M. (2000). Prospective study of work related respiratory symptoms in trainee bakers. Occup Environ Med 57(1):58-61.

http://dx.doi.org/10.1136/oem.57.1.58

de Zwart, B.C., Broersen, J.P., Frings-Dresen, M.H., van Dijk, F.J. (1997). Musculoskeletal complaints in The Netherlands in relation to age, gender and physically demanding work. Int Arch Occup Environ Health 70(5):352-360. http://dx.doi.org/10.1007/ s004200050229

Dyreborg, J., Nielsen, K., Kines, P., Dziekanska, A., Frydendall, K,B., Bengtsen, E., \& Rasmussen, K. (2013). Review af ulykkesforebyggelsen - review af den eksisterende videnskablige litteratur om effekten af forskellige typer tiltag til forebyggelse af arbejdsulykker (p 1-144). København, Danmark: Det Nationale Forskningscenter for Arbejdsmiljø.

Döös, M., Laflamme, L., \& Backström, T. (1994). Immigrants and occupational accidents: A comparative study of the frequency and types of accidents encountered by foreign and Swedish citizens at an engineering plant in Sweden. Safety Science 18:15-32. http://dx.doi.org/10.1016/0925-7535(94)90038-8

Einarsdóttir, M. (2014). Paid work of children and teenagers in Iceland, Participation and Protection. University of Iceland.

Einarsdóttir, M., Rafnsdóttir, G,L., \& Einarsdóttir, J. (2014). Vinnuslys ungmenna: Orsakir og alvarleiki [Work injuries of 13-17-year-old Icelanders: Causes and consequences]. 
Enberg, B., Nordin, C., \& Öhman, A. (2010). Work experiences in novice occupatonal therapists and physiotherapists in public sector employment - Analyses using two occupational stress models. Advances in Physiotherapy 12:42-49.

http://dx.doi.org/10.3109/14038190903033161

Eurostat (1998). European Statistics on Accidents at Work: Methods and definitions Theme 3. 1998 Edition edn. Luxembourg: Office for Official Publications of the European Communities.

Eurostat (2015). In: European Commission. http://ec.europa.eu/eurostat/data /database Accessed 15 August 2015.

Fangen, K. (2012). Young adults of ethnic minority background on the Norwegian labour market: The ineractional co-construction of exclusion by employers and customers. Ethnicities 13(5):607-624. http://dx.doi.org/10.1177/ 1468796812467957

Finegold, D., Mohrman, S., \& Spreitzer, G,M. (2002). Age effects on the predictors of technical workers' commitment and willingness to turnover. Journal of Organizational Behavior 23(5):655-674. http://dx.doi.org/10.1002/job.159

FIOH (2012). Työ ja terveys Suomessa 2012 - Seurantatietoa työoloista ja työhyvinvoinnista. Finnish Institute of Occupational Health, Helsinki.

Flinkman, M., Laine, M., Leino-Kilpi, H., Hasselhorn, H,M., \& Salantera, S. (2008). Explaining young registered Finnish nurses' intention to leave the profession: a questionnaire survey. Int J Nurs Stud 45(5):727-39. http://dx.doi.org/10.1016/ j.ijnurstu.2006.12.006

Franzén, E,M. \& Kassman, A. (2005). Longer-term labour-market consequences of economic inactivity during young adulthood: A Swedish national cohort study. Journal of Youth Studies 8(4):403-424.

Gerhardsson, L., Burstrom, L., Hagberg, M., Lundstrom, R., \& Nilsson, T. (2013). Quantitative neurosensory findings, symptoms and signs in young vibration exposed workers. J Occup Med Toxicol 8(1):8. http://dx.doi.org/10.1186/17456673-8-8

Gravseth, H,M., Lund, J., \& Wergeland, E. (2003). Arbeidsskader behandlet ved Legevakten i Oslo og Ambulansetjenesten. Tidsskr Nor Lægeforen 15:2060-4.

Gustavsson, J,P., Hallsten, L., Rudman, A. (2010). Early career burnout among nurses: modelling a hypothesized process using an item response approach. Int J Nurs Stud 47(7):864-75. http://dx.doi.org/10.1016/j.ijnurstu.2009.12.007

Hagberg, M., Thiringer, G., \& Brandstrom, L. (2005). Incidence of tinnitus, impaired hearing and musculoskeletal disorders among students enrolled in academic music education - a retrospective cohort study. Int Arch Occup Environ Health 78(7):57583. http://dx.doi.org/10.1007/s00420-005-0621-y

Halvorsen, B., Hansen, 0-J., \& Tägström, J. (2013). Young people on the edge. (TemaNord 2013:523). Copenhagen: Nordic Council of Ministers. http://dx.doi.org/10.6027/TN2013-536

Hammarström, A. \& Janlert, U. (2000). Do early unemployment and health status among young men and women affect their chances of later employment? Scan J Public Health 28:10-15.

Hammer, T. (1996). Consequences of unemployment in the transition from youth to adulthood in a life course perspective. Youth Soc 27(4):450-468.

http://dx.doi.org/10.1177/0044118X96027004003

Hammer T (1997). History dependence in youth unemployment. Eur Sociol Rev 13(1):17-33. http://dx.doi.org/10.1093/oxfordjournals.esr.a018204 
Hammer, T. (1999). The influence of different compensation levels of unemployment benefits on job chances among unemployed youth: A comparative study of the Nordic countries. Acta Sociol 42(2):123-134. http://dx.doi.org/10.1177/ 000169939904200202

Hammer, T. (2000). Mental health and social exclusion among unemployed youth in Scandinavia. A comparative study. Int J Soc Welf 9(1):53-63. http://dx.doi.org/ 10.1111/1468-2397.00108

Hammer, T. (2003). The probability for unemployed young people to re-enter education or employment: A comparative study in six Northern European countries. Brit J Sociol Educ 24(2):209-223. http://dx.doi.org/10.1080/0142569032000052588

Hammer, T. (2007). Labour market integration of unemployed youth from a life course perspective: the case of Norway. Int J Soc Welf 16(3):249-257. http://dx.doi.org/10.1111/j.1468-2397.2006.00467.x

Hanvold, T.N., Veiersted, K.B., \& Wærsted, M. (2010). A prospective study of neck, shoulder and upper back pain among technical school students entering working life. J AdolescHealth 46:488-494. http://dx.doi.org/10.1016/ j.jadohealth.2009.11.200

Hanvold, T.N., et al. (2013). The effect of work-related sustained trapezius muscle activity on the development of neck and shoulder pain among young adults. Scand J Work Environ Health 39(4):390-400. http://dx.doi.org/10.5271/sjweh.3357

Held, E., Wolff, C., Gyntelberg, F., \& Agner, T. (2001). Prevention of work-related skin problems in student auxiliary nurses: an intervention study. Contact Dermatitis 44(5):297-303. http://dx.doi.org/10.1034/j.1600-0536.2001.440509.x

Hoffmann, H.J., et al. (2003). Plasma C3d levels of young farmers correlate with respirable dust exposure levels during normal work in swine confinement buildings. Ann Agric Environ Med 10(1):53-60.

Hollund, B.E., Moen, B.E., Lygre, S.H., Florvaag, E., \& Omenaas, E. (2001). Prevalence of airway symptoms among hairdressers in Bergen, Norway. Occup Environ Med 58(12):780-785. http://dx.doi.org/10.1136/oem.58.12.780

Holte, K.A. \& Kjestveit, K. (2012). Young workers in the construction industry and initial OSH-training when entering work life. Work - a Journal of Prevention Assessment \& Rehabilitation 41:4137-4141. doi:Doi 10.3233/Wor-2012-0709-4137

Hultell, D. \& Gustavsson, J.P. (2011). Factors affecting burnout and work engagement in teachers when entering employment. Work 40(1):85-98. doi:10.3233/WOR2011-1209

Hultman, B. \& Hemlin, S. (2008). Self-rated quality of life among the young unemployed and the young in work in northern Sweden. Work - a Journal of Prevention Assessment \& Rehabilitation 30(4):461-472.

Khatun, M., Ahlgren, C., \& Hammarstrom, A. (2004). The influence of factors identified in adolescence and early adulthood on social class inequities of musculoskeletal disorders at age 30: a prospective population-based cohort study. Int J Epidemiol 33(6):1353-60. http://dx.doi.org/10.1093/ije/dyh237

Kines, P., Framke, E., Salmi, A., \& Bengtsen, E. (2013). Young workers' occupational safety and health risks in the Nordic countries. (TemaNord 2013:569). Nordic Council of Ministers, Copenhagen. http://dx.doi.org/10.6027/TN2013-569

Kjartansdóttir, S. (2013). Skills beyond School - National Background Report for Iceland. Ministry of Education. 
Kjestveit, K., Tharaldsen, J., \& Holte, K.A. (2011). Young and strong: What influences injury rates within building and construction? Safety Science Monitor(2):1-15.

Kmet, M.L., Lee, C.R., \& Cook, S.L. (2004). Standard Quality Assessment Criteria for Evaluating Primary Research Papers from a Variety of Fields. vol 13. Alberta, Canada: Alberta Heritage Foundation for Medical Research.

Knardahl, S., et al. (2008). Arbeid som årsak til muskelskjelettlidelser: Kunnskapsstatus 2008. Oslo: Statens Arbeidsmiljøinstitutt (STAMI).

Koivisto, P., Vuori, J., \& Nykyri, E. (2007). Effects of the School-to-Work Group Method among young people. J Vocat Behav 70(2):277-296. http://dx.doi.org/10.1016/ j.jvb.2006.12.001

Koivisto, P., Vuori, J., \& Vinokur, A.D. (2010). Transition to work: Effects of preparedness and goal construction on employment and depressive symptoms. Journal of Research on Adolescence 20(4):869-892. http://dx.doi.org/10.1111/j.1532-7795.2010.00667.x

Korpinen, L. \& Paakkonen, R. (2011). Physical symptoms in young adults and their use of different computers and mobile phones. Int J Occup Saf Ergon 17(4):361-71. http://dx.doi.org/10.1080/10803548.2011.11076899

Kristjánsson ÁL, Guðmundsdóttir ML, Pálsdóttir H, Sigfúsdóttir ID \& Sigfússon J (2008). Ungt fólk 2007: Framhaldsskólanemar: Menntun, menning, tómstundir, ípróttaiðkun og framtíðarsýn ungmenna í framhaldsskólum á Íslandi: Samanburður rannsókna frá 2000, 2004 og 2007 [Youth in Iceland 2007]. Reykjavík: Rannsóknir og greining, Ministry of education, science and culture.

Kunta 10-tutkimus (2012). Finnish instititue of Occupational Health, [10-Town study] Accessed 15 October 2015. http://www.ttl.fi/fi/tutkimus/hankkeet /kunta10_tutkimus/Sivut/default.aspx

Laflamme, L., Menckel, E., \& Stromberg, A. (1997). Age-related overexertion injuries among Swedish nursing auxiliaries over a 10-year period. Work 8(2):139-48. http://dx.doi.org/10.3233/WOR-1997-8204

Lind, M.L., et al. (2007). Incidence of hand eczema in female Swedish hairdressers. Occup Environ Med 64(3):191-5. http://dx.doi.org/10.1136/oem.2005.026211

Lindqvist, K., Schelp, L., \& Timpka, T. (1999). Gender aspects of work-related injuries in a Swedish municipality. Safety Science 31:183-196.

Loughlin, C. \& Frone, M.R. (2004) Young workers' occupational safety. In: J. Barling \& M.R. Frone (eds), The Psychology of Workplace Safety. Washington, DC: American Psychological Association.

Lundetræ, K., Gabrielsen, E., \& Mykletyn, R. (2010). Do basic skills predict youth unemployment (16- to 24-year-olds) also when controlled for accomlished uppersecondary school? A cross-country comparison. Journal of Education and Work 23(3):233-254. http://dx.doi.org/10.1080/13639081003745439

Lysdal, S.H., Sosted, H., Andersen, K.E., \& Johansen, J.D. (2011). Hand eczema in hairdressers: a Danish register-based study of the prevalence of hand eczema and its career consequences. Contact Dermatitis 65(3):151-8. http://dx.doi.org/10.1111/ j.1600-0536.2011.01935.x

Malmberg-Heimonen I \& Julkunen, I. (2006). Out of unemployment? A comparative analysis of the risks and opportunities longer-term unemployed immigrant youth face when entering the labour market. Journal of Youth Studies 9(5):575-592. http://dx.doi.org/10.1080/13676260601021054 
Marlenga, B., Berg, R.L., \& Linneman, J.G., Wood, D.J., Kirkhorn, S.R., \& Pickett, W. (2012). Determinants of early-stage hearing loss among a cohort of young workers with 16-year follow-up. Occup Environ Med 69(7):479-84. http://dx.doi.org/ 10.1136/oemed-2011-100464

Merlino, L.A., Rosecrance, J.C., Anton, D., \& Cook, T.M. (2003). Symptoms of musculoskeletal disorders among apprentice construction workers. Appl Occup Environ Hyg 18(1):57-64. http://dx.doi.org/10.1080/10473220301391

Mikkonen, P., et al. (2012). Physical workload and risk of low back pain in adolescence. Occup Environ Med 69(4):284-90. http://dx.doi.org/10.1136/oemed2011-100200

Ministry of Education, Science and Culture. 2014. [White Paper on educational reform]. (In Icelandic: Hvítbók um umbætur í menntun).

Ministry of Welfare. 2015. [Results on forming a suggestion on policy and organization of labour market issues in Iceland]. (In Icelandic: Niðurstöður nefndar um mótun tillögu að vinnumarkaðsstefnu og skipulagi vinnumarkaðsmála á Íslandi).

Muhr, P. \& Rosenhall, U. (2010). Self-assessed auditory symptoms, noise exposure, and measured auditory function among healthy young Swedish men. Int J Audiol 49(4):317-25. http://dx.doi.org/10.3109/14992020903431280

Musset, P \& Castaneda Valle R. 2013. A Skills beyond School Commentary on Iceland. OECD Reviews of Vocational Education and Training.

NFA (2013). Arbejdsmiljø og helbred i Danmark - Resumé og resultater. National Forskninscenter for Arbejdsmiljø (National Research Centre for the Working Enviroment), Denmark.

Nielsen, H.S., Rosholm, M., Smith, N., \& Husted L. (2003). The school-to-work transition of 2(nd). generation immigrants in Denmark. J Popul Econ 16(4):755786. http://dx.doi.org/10.1007/s00148-003-0164-z

Nielsen, M.L. (2012). Adapting “The Normal” - Examining Relations between Youth, Risk and Accidents at Work. Nordic Journal of working life studies 2(2). http://dx.doi.org/10.19154/njwls.v2i2.2358

Nielsen, M.L., Dyreborg, J., Kines, P., Nielsen, K.J., \& Rasmussen, K. (2013). Exploring and Expanding the Category og "Young Workers" According to Situated Ways og Doing Risk and Safety - a Case Study in the Retail Industry. Nordic Journal of working life studies 3(3). 219-243. http://dx.doi.org/10.19154/njwls.v3i3.3019

Nilsen, O.A., Risa, A.E., Torstensen, A. (2000). Transitions from employment among young Norwegian workers. J Popul Econ 13(1):21-34. http://dx.doi.org/10.1007/ s001480050120

NOA (2015). Faktabok om arbeidsmiljø og helse 2015. Status og utviklingstrekk STAMI-rapport. vol 16. Norway.

Olofsson, J. \& Wadensjö, E. (2012). Youth, education and labour market in the Nordic countries. Berlin, Germany: Friedrich-Ebert-Stiftung.

Omland, O., Sigsgaard, T., Hjort, C., Pedersen, O.F., \& Miller, M.R. (1999). Lung status in young Danish rurals: the effect of farming exposure on asthma-like symptoms and lung function. Eur Respir J 13(1):31-7. http://dx.doi.org/10.1183/ 09031936.99.13103199

Palassis, J., Schulte, P.A., Sweeney, M.H., Okun, A.H. (2004). Enhancing occupational safety and health through use of the national skill standards. Int J Occup Environ Health 10(1):90-8. http://dx.doi.org/10.1179/oeh.2004.10.1.90

Pedersen, J., Bjorner, J.B., Burr, H., \& Christensen, K.B. (2012). Transitions between sickness absence, work, unemployment, and disability in Denmark 2004-2008. Scand J Work Env Hea 38(6):516-526. http://dx.doi.org/10.5271/sjweh.3293 
Rasmussen, K., Hansen, C.D., Nielsen, K.J., \& Andersen, J.H. (2011). Incidence of work injuries amongst Danish adolescents and their association with work environment factors. AmJIndMed 54(2):143-152. http://dx.doi.org/10.1002/ajim.20911

Reine, I., Novo, M., \& Hammarström, A. (2008). Does transition from an unstable labour market position to permanent employment protect mental health? Results from a 14-year follow-up of school-leavers. Bmc Public Health 8. doi:Artn 15910.1186/1471-2458-8-159

Reine, I., Novo, M., \& Hammarström, A. (2011). Is participation in labour market programmes related to mental health? Results from a 14-year follow-up of the Northern Swedish Cohort. Scand J Public Healt 39(1):26-34. http://dx.doi.org/ 10.1186/1471-2458-8-159

Rögnvaldsdottir, S. (2015). Kynferdisleg áreitni gagnvart starfsfólki i pjónustustörfum [Sexual harassment towards workers in service sector]. The Federation of General and Special Workers in Iceland (SGS), Iceland.

Salminen, S. (1996). Work-related accidents among young workers in Finland. International Journal of Occupational Safety and Ergonomics 2(4):305-314.

Sigsgaard, T., Hjort, C., Omland, Ø., Miller, M.R., \& Pedersen, O.F. (1997). Respiratory Health and Allergy among young farmers and non-farming rural males in Denmark: The SUS study. Journal of Agromedicine 4(1):63-73. http://dx.doi.org/10.1300/ J096v04n01_09

Sigursteinsdottir, H. (2012). Einelti á vinnustad i kjölfar efnahagshrunsins 2008 [Bullying at the workplace after the economic crisis in 2008]. University of Iceland, Iceland.

Skjold, T., Dahl, R., Juhl, B., \& Sigsgaard, T. (2008). The incidence of respiratory symptoms and sensitisation in baker apprentices. Eur Respir J 32(2):452-459. http://dx.doi.org/10.1183/09031936.00108207

Skjold, T., Nielsen, S.C., Adolf, K., Hoffmann, H.J., Dahl, R., \& Sigsgaard T (2007). Allergy in bakers' apprentices and factors associated to non-participation in a cohort study of allergic sensitization. Int Arch Occup Environ Health 80(5):458-464. http://dx.doi.org/10.1007/s00420-006-0151-2

Skogstad, M., Haldorsen, T., Arnesen, A.R., \& Kjuus, H. (2005). Hearing thresholds among young professional divers: A 6-year longitudinal study. Aviat Space Environ Med 76(4):366-369.

Støren, L.A. (2011). Key Factors behind Labour Market Marginalization of Young Immigrants: Limited Access to Apprenticeships, "State Dependence" or Low Qualifications? Young 19(2):129-158. http://dx.doi.org/10.1177/110330881001900202

Sulander, J., Viluksela, M., Elo, A., Huuskonen, M., \& Leino, T. (2006). Nuoret ja työ 2006 barometri Taulukkoraportti. Helsinki: Työterveyslaitos.

Svensson, A.L., et al. (2009). Multidimensional intervention and sickness absence in assistant nursing students. OccupMed(Lond) 59(8):563-569. http://dx.doi.org/ 10.1093/occmed/kqp124

Søvik, S.R., Lysberg, K., \& Røyset, S.E. (2009). Arbeidsskader blant unge arbeidstakere i bygge- og anleggsbransjen. Oslo: Direktoratet for arbeidstilsynet.

Taimela, S., et al. (2007). Self-reported health problems and sickness absence in different age groups predominantly engaged in physical work. Occup Environ Med 64:739-746. http://dx.doi.org/10.1136/oem.2006.027789

Tómasson, K., et al. (2011). Fatal Occupational Accidents in the Nordic Countries 2003-2008. (TemaNord vol 501). (p 1-40) Copenhagen: Nordic Council of Ministers. http://urn.kb.se/resolve?urn=urn:nbn:se:norden:org:diva-1395 
Tyssen, R., Vaglum, P., Gronvold, N.T., \& Ekeberg, O. (2000). The impact of job stress and working conditions on mental health problems among junior house officers. A nationwide Norwegian prospective cohort study. Med Educ 34(5):374-384. http://dx.doi.org/10.1046/j.1365-2923.2000.00540.x

Tyssen, R., Vaglum, P., Gronvold, N.T., \& Ekeberg, O. (2001a). Suicidal ideation among medical students and young physicians: a nationwide and prospective study of prevalence and predictors. J Affect Disord 64(1):69-79. http://dx.doi.org/ 10.1016/S0165-0327(00)00205-6

Tyssen, R., Vaglum, P., Gronvold, N.T., \& Ekeberg, O. (2001b). Factors in medical school that predict postgraduate mental health problems in need of treatment. A nationwide and longitudinal study. Med Educ 35(2):110-120. http://dx.doi.org/ 10.1046/j.1365-2923.2001.00770.x

Tyssen, R., Vaglum, P., Gronvold, N.T., \& Ekeberg, O. (2005). The relative importance of individual and organizational factors for the prevention of job stress during internship: a nationwide and prospective study. Med Teach 27(8):726-731. http://dx.doi.org/10.1080/01421590500314561

Uter, W., Pfahlberg, A., Gefeller, O., \& Schwanitz, H.J. (1999). Hand dermatitis in a prospectively-followed cohort of hairdressing apprentices: final results of the POSH study. Prevention of occupational skin disease in hairdressers. Contact Dermatitis 41(5):280-6. http://dx.doi.org/10.1111/j.1600-0536.1999.tb06162.x

van der Wel, K.A. (2011). Long-term effects of poor health on employment: the significance of life stage and educational level. Sociol Health Illn 33(7):1096-1111. http://dx.doi.org/10.1111/j.1467-9566.2011.01346.x

van Tulder, M., Furlan, A., Bombardier, C., \& Bouter, L. (2003). Updated method guidelines for systematic reviews in the cochrane collaboration back review group. Spine (Phila Pa 1976) 28(12):1290-1299. http://dx.doi.org/10.1097/ 01.BRS.0000065484.95996.AF

Videman, T., Ojajarvi, A., Riihimaki, H., \& Troup, J.D. (2005). Low back pain among nurses: a follow-up beginning at entry to the nursing school. Spine 30(20):23342341. http://dx.doi.org/10.1097/01.brs.0000182107.14355.ca

Vinokur, A.D., Price, R.H., \& Schul, Y. (1995). Impact of the JOBS intervention on unemployed workers varying in risk for depression. Am J Community Psychol 23(1):39-74. http://dx.doi.org/10.1007/BF02506922

Virtanen, M., Kivimäki, M., Joensuu, M., Virtanen, P., Elovainio, M., \& Vahtera, J. (2005). Temporary employment and health: a review. IntJEpidemiol 34(3):610622. (doi:dyi024 [pii]) http://dx.doi.org/10.1093/ije/dyi024

Vuori, J., Price, R.H., Mutanen, P., \& Malmberg-Heimonen, I. (2005). Effective group training techniques in job-search training. J Occup Health Psychol 10(3):261-75. doi:10.1037/1076-8998.10.3.261

Vuori, J., Silvonen, J., Vinokur, A.D., \& Price, R.H. (2002). The Tyohon Job Search Program in Finland: benefits for the unemployed with risk of depression or discouragement. J Occup Health Psychol 7(1):5-19.

Vuori, J., Toppinen-Tanner, S., \& Mutanen, P. (2012). Effects of resource-building group intervention on career management and mental health in work organizations: randomized controlled field trial. J Appl Psychol 97(2):273-86. http://dx.doi.org/10.1037/a0025584

Wahlström, J., Burström, L., Hagberg, M., Lundström, R., \& Nilsson, T. (2008). Musculoskeletal symptoms among young male workers and associations with exposure to hand-arm vibration and ergonomic stressors. Int Arch Occup Environ Health 81(5):595-602. http://dx.doi.org/10.1007/s00420-007-0250-8 
Walusiak, J., Hanke, W., Gorski, P., \& Palczynski, C. (2004). Respiratory allergy in apprentice bakers: do occupational allergies follow the allergic march? Allergy 59(4):442-50. http://dx.doi.org/10.1111/j.1398-9995.2003.00418.x

Wendelborg, C., Thorshaug, K., Paulsen, V., Garvik, M. (2014). Lærlingundersøkelsen [Apprenticesurvey] Report. Trondheim: NTNU Samfunnsforskning.

WHO (1994) Global Strategy on occupational health for all: The way to health at work. Recommendation of the second meeting of the WHO Collaborating Centres in Occupational Health, 11-14 October 1994, Bejing, China. Geneva.

Zwetsloot, G.I.J.M, Kines, P., Ruotsala, R., Drupsteen, L. \& Bezemer, R. (2015). Success factors for the implementation of a Zero Accident Vision. TNO Report R11506, Netherlands. 



\section{Sammendrag}

Formålet med denne rapporten er å sammenligne Nordisk statistikk om unge arbeidstakeres sikkerhet, helse og arbeidsdeltakelse, i tillegg til å systematisk og kritisk gjennomgå den vitenskapelig litteraturen på sikkerhet, helse og deltakelse blant unge arbeidstakere i de nordiske landene. Det er også ønskelig å samle nordiske erfaringer om utfordringer og politiske initiativer når det gjelder unge arbeidstakere. Data fra Eurostat og Nasjonale Levekårsundersøkelser ble brukt til å sammenligne statistikk fra de fem Nordiske land. Den vitenskapelige litteratur utgitt mellom 1994 og 2014 med fokus på unge arbeidstakere i de nordiske landene ble gjennomgått og sammenlignet med internasjonale studier. Intervjuer og en nordisk workshop med inviterte interessenter ble brukt til å samle nordiske erfaringer på området.

De nasjonale undersøkelsene viser at unge arbeidstakere i de nordiske landene har mange liknende arbeidsrelaterte helseutfordringer. Unge arbeidstakere (15-34 år) har opptil 40 \% økt risiko for arbeidsrelaterte psykiske problemer sammenlignet med eldre arbeidstakere. De har opptil $70 \%$ øt risiko for arbeidsrelatert hodepine, og over tre ganger økt risiko for arbeidsrelaterte hudproblemer i forhold til eldre arbeidstakere. Litteraturgjennomgangen viser at yrkesrelatert kjemisk eksponering, tunge mekaniske belastninger og psykososial arbeidsbelastning var signifikante risikofaktorer for arbeidsrelaterte helseproblemer blant unge arbeidstakere i de nordiske landene.

Den nordiske statistikken viser at unge arbeidstakere er mer utsatt for uheldige arbeidsbelastninger. Unge arbeidstakere har opptil $70 \%$ høyere risiko for rapportering av tungt fysisk arbeid, for eksempel håndtering av tung last, og de har opptil dobbelt så høy risiko for en ulykke på jobben. Høyest forekomsten av ulykker finnes blant unge arbeidstakere i jordbruk, skogbruk og fiske. Unge mannlige arbeidere i de nordiske landene har høyere risiko for ulykker i forhold til unge kvinnelige arbeidstakere, men dette skyldes i hovedsak unge mannlige arbeideres tendens til å arbeide på arbeidsplasser som er mer ulykkes utsatt og har flere farlige oppgaver i forhold til kvinnelige arbeidstakere. Den vitenskapelige litteraturgjennomgangen viser at fysisk krevende arbeid som tunge løft, psykososiale arbeidsbelastninger, sikkerhetsklima og risikososialisering er faktorer knyttet til arbeidsulykker blant unge 
arbeidstakere i de nordiske landene. Det fremgår av denne rapporten at det er en mangel på studier og kunnskap om effekten av forebyggende tiltak vedrørende unge arbeidere og arbeidsulykker og arbeidsrelatert helse i Norden. Likeledes er det en mangel på kunnskap om hvordan bedrifter og ledere forstår og praktiserer HMS, og deres rolle i å bidra til et bærekraftig sunt arbeidsliv for unge arbeidstakere.

Nordiske erfaringer understreker viktigheten av å unngå stereotypier og fremhever at de unge arbeidstakere utgjør en heterogen gruppe. Det å endre fokus fra den unge til et bredere syn på HMS på arbeidsplassen og sikkerhetsklima i bedriften der unge mennesker arbeider er også avgjørende. Mange unge arbeidstakere er i ufaglærte og midlertidig arbeid, hvor de ofte mangler HMS opplæring og erfaring. Dette understreker betydningen av å sikre kvalifisert og strukturert introduksjon, veiledning og oppfølging av HMS på arbeidsplassen.

Basert på intervjuer av personer i de nordiske yrkesutdanninginstitusjonene gir rapporten også forslag for å forbedre HMS utdanning for yrkesfagelever. Selv om alle de fem nordiske landene har konkrete kompetansemål for HMS kunnskap i de yrkesfaglige utdanningsprogrammene, er det en mangel på standardisert HMS opplæring. HMS opplæringen blir da i stor grad påvirket av lærernes/skolens entusiasme, erfaring og tilgjengelig tid og ressurser.

De nordiske landene står overfor mange av de samme utfordringene når det gjelder arbeidsdeltakelse blant unge voksne. Rapporten viser at midlertidige ansettelser er vanlig blant unge arbeidstakere. De arbeider ofte i (mer enn en) deltidsjobb og har atypisk arbeidstid. Sysselsettingen blant unge var noe forskjellig mellom landene, og spenner seg fra $42 \%$ i Sverige til $70 \%$ på Island. Den vitenskapelige litteraturgjennomgangen viser at tidlig arbeidsledighet, lav selvvurdert helse, etnisk minoritet og frafall fra skolen var alle faktorer som var assosiert med lav arbeidsdeltakelse blant unge arbeidstakere i de nordiske landene. Intervensjonsstudier har vist at å forberede elevene på yrkesfaglige skoler for arbeidslivet ved å øke deres opplevelse av mestring fører til økt sysselsetting blant unge arbeidstakere. Det å forberede unge voksne for arbeidslivet er viktig, men det er klart at arbeidsdeltakelse blant unge arbeidstakere påvirkes av flere faktorer som for eksempel individuelle, sosiale, yrkesmessige og strukturelle forhold.

Denne rapporten viser at de nordiske landene har mange av de samme utfordringer og et bredt spekter av politiske initiativ for å forbedre både helse, sikkerhet og arbeidsdeltagelse blant unge arbeidstakere. Effektene av disse initiativene er imidlertid sjelden evaluert. Denne rapporten viser et behov for en tverrfaglig og helhetlig tilnærming for å sikre en sunt 
arbeidsliv blant unge arbeidstakere. I forsøket på å øke vår forståelse av unge arbeidstakernes helse, sikkerhet og deltakelse er det viktig å ta hensyn til flere faktorer som spiller inn: å være ung, den enkelte arbeidstaker, arbeidsplassen, arbeidsoppgavene, utdanningen og sysselsettingen. De funn, konklusjoner og anbefalinger vi gir i denne rapporten vil forhåpentligvis bidra til å bedre arbeidsforholdene for unge arbeidstakere i de nordiske land gjennom fremtidig samarbeid, politiske initiativ og forskning. 
Nordic Council of Ministers

Ved Stranden 18

DK-1061 Copenhagen $\mathrm{K}$

www.norden.org

Young workers and sustainable work life

A sustainable working life that prevents work-related health problems and facilitates inclusion of young workers is vital to ensure the health, safety and work participation among young workers in the Nordic countries. This report provides Nordic statistics, scientific knowledge and discussions on how to achieve a sustainable work life for young workers in the Nordic countries.

Under the Swedish presidency of the Nordic Council of Ministers in 2013, the focus was on youth and young workers' working conditions. As part of this focus, the Nordic Council of Ministers commissioned this report.

The report shows that an inter-disciplinary and comprehensive approach is essential to ensure a sustainable work life among young workers. Six characteristics are emphasized as important: the characteristics of the worker, the workplace, the work task, the employment, the education and the youth.

TemaNord 2016:512

ISBN 978-92-893-4498-2 (PRINT)

ISBN 978-92-893-4499-9 (PDF)

ISBN 978-92-893-4500-2 (EPUB)

ISSN 0908-6692

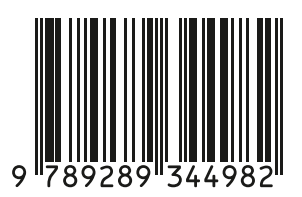

